\title{
Impact of Mandatory IFRS Adoption on Conditional Conservatism in Europe
}

\section{Research Center \\ ESSEC Working Paper 1311}

2013

Paul André

Andrei Filip

Luc Paugam 


\title{
Impact of Mandatory IFRS Adoption on Conditional Conservatism in Europe
}

\author{
Paul André*, Andrei Filip and Luc Paugam \\ ESSEC Business School
}

27 August 2013

\begin{abstract}
Acknowledgements:
We are grateful for the valuable comments received from Mary Barth, Gilles Hilary, Wayne Landsman, Steven Monahan, and other workshop participants of the joint ESSEC-INSEAD research seminar and the Catholic University of Leuven seminar. The authors would also like to thank the participants of the $32^{\text {nd }}$ French Accounting Association Conference - Montpellier 2011, the $6^{\text {th }}$ Accounting and Management Information Systems Conference - Bucharest 2011, the $10^{\text {th }}$ International Conference on Governance - Montreal 2011, the Financial Reporting and Business Communication Conference - Bristol 2011, the EUFIN Conference, Bamberg 2011, the Accounting and Auditing Convention - Cluj-Napoca 2011 and the European Accounting Association Conference, Ljubljana 2012, for their helpful comments and suggestions. Paul André and Andrei Filip thank the Autorité des Normes Comptables for financial support. Paul André also thanks the ESSEC KPMG Financial Reporting Centre.
\end{abstract}

*Corresponding author: andre@essec.edu 


\title{
Impact of Mandatory IFRS Adoption on Conditional Conservatism in Europe
}

\begin{abstract}
We study the effect of the mandatory adoption of IFRS in Europe in 2005 on conditional conservatism. To capture conditional conservatism, we use three measures: the Basu (1997) measure, the Khan and Watts (2009) measure, and a measure controlling for potential shifts in unconditional conservatism and cost of capital after the adoption of IFRS. From a sample of 7,251 firm-year observations drawn from 16 European countries, we document an overall decline of the degree of conditional conservatism across our three measures. While there is no change in weak enforcement/governance countries which remain less conditionally conservative than strong enforcement/governance countries, the latter exhibit a significant decrease. Further, we demonstrate that the decline is more significant for firms carrying intangible assets and goodwill in their balance sheets, items for which impairment tests rely on unverifiable fair value estimates. We argue that IFRS are conceptually conditionally conservative but that inappropriate application of conditional conservatism principles may have prevented financial reporting from reaching the level of conservatism targeted by the IASB.
\end{abstract}

Key words: Conditional Conservatism, IFRS, Europe, Enforcement, Governance, Intangibles, Impairment

JAL: M41, M48, G38 


\section{INTRODUCTION}

The mandatory adoption of International Financial Reporting Standards (IFRS) by a large number of European listed firms in 2005 resulted in a major accounting change. Domestic GAAP shaped by local institutions and regulations and embedded into national economies and cultures were abandoned for a single set of principle-based accounting standards. One of the major intended purposes of the adoption of IFRS was to enhance financial reporting through the requirements of a set of 'high quality standards'. We examine if the adoption of IFRS resulted in an improvement of financial reporting quality, in particular in the degree of conditional conservatism of financial reporting.

Conditional conservatism is the greater aggressiveness in the recognition of bad news than in the recognition of good news and is considered a key qualitative characteristic of financial reporting (Watts, 2003a; Francis et al., 2004; Francis et al., 2006; Ball et al., 2008; Dechow et al., 2010; Kothari et al., 2010). This form of news-dependent prudence ensures that potential economic losses are reported in a timely fashion in earnings, whereas the recognition of potential economic gains is delayed. Conditional conservatism is distinguished from unconditional conservatism, also known as ex ante or news-independent prudence, consisting in continually understating the book value of net assets relatively to their economic value, independently from any news (Pope and Walker, 2003; Beaver and Ryan, 2005).

The effect of the adoption of IFRS on conditional conservatism is a priori unclear. Indeed, it is often argued by observers (like the press) that IFRS are 'less prudent' than national GAAP and they point out two arguments. First, the term 'prudence' has been removed from the conceptual framework (IASB, 2010). Second, IFRS allow various fair value options that would be imprudent per se. Regarding the first argument, according to the IASB prudence conflicts with the quality of neutrality, but in reality, the Board explained in 2008 that " $[\mathrm{t}]$ he exercise of prudence does not allow for deliberate understatement of assets or income or overstatement of liabilities or expenses. [...] Introducing bias in understatement of assets (or overstatement of liabilities) in one period frequently leads to overstating financial performance in later periods - a result that cannot be described as prudent" (IASB, 2008, § BC2.21). The form of 'prudence' that the Board intended to eliminate from the conceptual framework (and financial reporting) can be clearly related to unconditional conservatism, not to conditional conservatism. It is also clear that the Board describes the negative relation between unconditional conservatism and conditional conservatism (Pope and Walker, 2003; 
Beaver and Ryan, 2005). Additionally, regarding the second argument, fair value for financial assets does not significantly impact many industries other than the financial sector, and if firms decide to follow the fair value option, both unrealized gains (good news) and unrealized losses (bad news) are recognized in earnings (or other comprehensive income). Fair value cannot be considered less conditionally conservative than amortized cost. ${ }^{1}$

Conversely, IFRS do include various mechanisms ensuring the application of conditional conservatism, such as the recognition of probable liabilities vs. the nonrecognition of contingent assets (IAS 37), the lower of cost or net realizable values for inventories (IAS 2), or impairment for financial assets and long-lived assets (IAS 39 and IAS 36 ), to name a few. For instance, directly translating the idea of conditional conservatism, IAS $36 \S 1$ states "The objective of this standard is to prescribe the procedures that an entity applies to ensure that its assets are carried at no more than their recoverable amount. [...] If this is the case, the asset is described as impaired and the standard requires the entity to recognise an impairment loss [in earnings]."

Therefore, from a conceptual perspective IFRS can be considered as conditionally conservative. Ceteris paribus, the adoption of IFRS should lead to an increase in the degree of conditional conservatism at least in countries that had 'less stringent' accounting standards in the pre-IFRS era. However, there is evidence that the application of the considerable discretion permitted by IFRS may have prevented financial reporting from reaching the level of conditional conservatism targeted by the IASB. Christensen et al. (2008), examining voluntary adopters vs. mandatory adopters in Germany, already showed that "the flexibility embedded in IFRS might render it ineffective in restricting earnings management of firms with low incentives to comply." Similarly, there are particular concerns about a potential inappropriate application and enforcement of impairment tests which can arguably be considered as IFRS' main mechanism ensuring conditional conservatism. Indeed, impairment tests have three important characteristics. First, they affect conditional conservatism (Kim et al., 2013), as impairment tests ensure that assets are not carried at more than their economic value (also referred to as 'recoverable value' IAS $36 \S 1$ ). IFRS require that an impairment loss be recognized in earnings whenever the recoverable amount is below the carrying amount

\footnotetext{
1 Under IAS 16, optional revaluations of property, plant and equipment are recorded as a gain in other comprehensive income (OCI). Subsequent negative fair value adjustments are first recorded as a loss in OCI (as a reversal of the previously booked gains), and then as a loss in earnings. Under IAS 40, both gains and losses of investment properties are included in earnings under the fair value option. Under IAS 39, both gains and losses on financial instruments designated at fair value affect earnings while only significant loss (impairment) affect earnings for financial instruments measured at cost.
} 
(IAS $36 \S 59$ ). Second, impairment testing needs to be applied to a large proportion of balance sheet items (all tangible and intangible fixed assets, including goodwill). ${ }^{2}$ Third, they are relevant to non-financial sectors. The implementation of impairment tests (in particular for intangibles with indefinite useful life) usually relies on valuation models, requires 'significant judgment' from managers (Petersen and Plenborg, 2010, 420), and is prone to manipulation by managers because it relies on unverifiable fair value estimates (Hayn and Hughes, 2006; Ramanna, 2008; Bens et al., 2011; Li and Sloan, 2011; Ramanna and Watts, 2012). ${ }^{3}$ The European Securities and Market Authority (ESMA) recently expressed concerns about insufficient impairment recognition by major listed European companies during the financial crisis (see ESMA, 2013). Various professional reports by large auditors or other consulting firms have also documented this lack of recognition of economic impairment for several years. ${ }^{4}$ Further studies have documented an incomplete and heterogeneous level of compliance with disclosure requirements under IFRS 3 and IAS 36 (Amiraslani et al. 2013; Mazzi et al. 2013; Tsalavoutas et al. forthcoming). Finally, the press recently echoed insufficient and untimely recognition of economic impairment for goodwill. ${ }^{5}$ The effect of the adoption of IFRS in 2005 on conditional conservatism in Europe remains therefore an empirical question and the effect is most likely dependent on the capacity to enforce various conditional conservatism mechanisms, among which impairment testing principles for nonfinancial assets play a critical role.

In this paper, we address the following research questions: what is the effect of the adoption of IFRS in 2005 on conditional conservatism? Can we relate a potential change of the degree of conditional conservatism to institutional factors and/or inappropriate application/enforcement of particular accounting mechanisms?

We examine pre and post levels of conditional conservatism for a sample of European firms that adopted IFRS in 2005, comprising 7,251 firm-year observations spanning from 2002 to 2007 that covers 16 countries (Austria, Belgium, Denmark, Germany, Finland,

\footnotetext{
${ }^{2}$ According to IAS $36 \S 2$ : Impairment testing procedures cover all assets but the following: inventories (IAS 2), construction contracts' assets (IAS 11), deferred tax assets (IAS 12), post-employment benefit assets (IAS 19), financial instruments (IAS 39), investment property measured at fair value (IAS 40), biological assets measured at fair value (IAS 41), specific assets that arise from insurance contracts (IFRS 4), and non-current assets held for sale and discontinued operations (IFRS 5).

${ }^{3}$ Most intangible assets, in particular goodwill, were amortized in domestic GAAP before the adoption of IFRS over periods ranging from 5 to 20 years (Nobes and Parker, 2010).

4 See Ernst \& Young (2010) 'Meeting today's financial challenges - Impairment reporting: Improving stakeholder confidence' and Houlihan Lokey (2013) 'The European Goodwill Impairment Study 2012-2013'

5 See Tata Steel - Goodwill Hunting, May $14^{\text {th }}$, 2013 on the website of The Economist. Available at: http://www.economist.com/news/business/21578082-what-corus-write-reveals-goodwill-hunting
} 
France, Great Britain, Greece, Ireland, Italy, Netherlands, Norway, Portugal, Spain, Sweden, and Switzerland). We use three empirical specifications to measure the levels of conditional conservatism: (1) the measure suggested by Basu (1997) that has been widely used in the literature (see Ryan, 2006), (2) the firm-year version of the Basu (1997) measure suggested by Khan and Watts (2009), and (3) an extension of the latter that we propose to control for the effects of shifts in unconditional conservatism and cost of capital after the adoption of IFRS. ${ }^{6}$ Next, we explore which institutional factors are associated to a change (or lack of a change) in the degree of conditional conservatism after the adoption of IFRS in 2005. We use cluster analysis based on several institutional dimensions well documented in the literature (La Porta et al., 1997, 1998), i.e., the strength of legal enforcement, the level of corporate governance, and a combination of various institutional factors (Leuz et al., 2003; Ball et al., 2008). Finally, we explore the role played by impairment tests in the change of the degree of conditional conservatism. We use the total amount of intangible assets and goodwill carried in balance sheets for several reasons: (1) impairment tests for goodwill and other intangible assets with indefinite useful life are required to be done at least once a year, (2) the valuation for such assets is subjective as management relies on 'value-in-use' as opposed to 'fair value less cost to sell' to compute recoverable value (Petersen and Plenborg, 2010), (3) the literature demonstrates that impairment tests for goodwill, which represents the bulk of recognized intangibles, appear to be manipulated (Hayn and Hughes, 2006; Ramanna, 2008; Bens et al., 2011; Li and Sloan, 2011; Ramanna and Watts, 2012).

We document the following results. First, we show that conditional conservatism has decreased after the mandatory adoption of IFRS in Europe in 2005. This result holds across our three measures of conditional conservatism, even after controlling for shifts in the degree of unconditional conservatism and cost of capital. Yet, the change in conditional conservatism is heterogeneous across several institutional dimensions. While there is no change in weak enforcement/governance countries which remain less conditionally conservative than strong enforcement/governance countries, the latter exhibit a significant decrease. This confirms results by Ahmed et al. (2013) who examine the effect of IFRS adoption on several proxies for accounting quality and suggest that enforcement mechanisms in these countries were unable to limit the greater flexibility of IFRS relative to domestic GAAP.

\footnotetext{
${ }^{6}$ Pope and Walker (1999) show that conditional conservatism is related to cost of capital and various studies demonstrate that cost of capital was affected by the adoption of IFRS (e.g., Karamanou and Nishiotis, 2009; Li, 2010; Daske et al., 2013).
} 
Second, clustering countries across multiple dimensions, namely legal, governance, enforcement and reliance on equity markets (Leuz et al., 2003; Ball et al., 2008), we show that insider economies with less developed stock market, concentrated ownership, weak investor rights but strong enforcement experience a decrease in conditional conservatism. European countries with large stock market, dispersed ownership, and strong investor rights and enforcement also experience a decrease in the degree of conditional conservatism after 2005. Conversely, insider economies with concentrated ownership, relatively narrow stock market, and weak enforcement experience no change in the degree of conditional conservatism. For this last set of countries, Hope (2003) and Ahmed et al. (2013) argue that accounting standards are to some extent inconsequential. Taken together, it appears that enforcement was unable to limit the decrease in conditional conservatism.

Third, we document that firms carrying intangibles or goodwill in their balance sheets become less conditionally conservative after the adoption of IFRS in 2005 whereas firms that had no intangibles or goodwill in their balance sheets experienced no change. Impairment tests for intangible assets are the most sensitive to management assumptions and are more likely to be manipulated. This result is consistent with Kim et al. (2013) that demonstrate a decrease in conditional conservatism in the US after the adoption of SFAS 142 introducing impairment testing for goodwill and other intangible assets in 2001. We observe a similar effect in Europe after the adoption of IFRS which introduced similar impairment principles. This result suggests that impairment principles may be inappropriately enforced by European regulators, in particular in traditionally 'strong enforcement' countries. We identify one important accounting mechanism that potentially explains at least some of the decrease in the degree of conditional conservatism.

We make several contributions to the literature. First, we add to the current literature on the intended and unintended consequences of accounting regulation on financial reporting quality (Brüggemann et al., 2013). Second, focusing on a key dimension of accounting quality, we demonstrate that although IFRS can be generally considered conditionally conservative, we observe a decrease after the adoption of IFRS, decrease most significant in strong enforcement/governance countries. Third, we identify a potential explanation: the deficiency in the application of likely the most important conditional conservatism mechanism, namely impairment tests. Further, our analysis reveals that countries traditionally considered as 'strong enforcers' were unable to apply the principles ensuring conditional conservatism. 
The rest of this paper is organised as follows. In section 2, we present a brief review of the literature and discuss factors that might affect conditional conservatism following the mandatory adoption of IFRS in Europe. In section 3, we review the related literature. In section 4, we develop our hypotheses. In section 5, we present our empirical model and sample. In section 6, we discuss our results and robustness tests. We conclude with implications of our research in section 7.

\section{CONSERVATISM IN ACCOUNTING AND ADOPTION OF IFRS}

Dickhaut et al. (2010), citing Littleton (1941), suggest that the principle of conservatism has been around since the $15^{\text {th }}$ century, pre-dating Pacioli's treatise on accounting bookkeeping. They argue that, by limiting the overstatement of net assets and income, conservatism constrains actions that could harm one's reputation in a multi-period world of exchanges based on reciprocity.

Watts (2003a) offers four explanations for the demand for conservatism - defined as "the differential verifiability required for recognition of profits vs. losses" (p. 207). First, conservatism is an efficient contracting mechanism - in the sense that it contributes to maximize firm value - since it limits managerial opportunism and counters managerial bias. Indeed, conservatism constrains opportunistic payments by management to itself (compensation) or to other parties such as shareholders (dividends). Second, conservatism limits litigation costs which are more likely when a firm overstates its earnings and net assets. Third, conservatism reduces the present value of a firm's taxes, since taxable income and reported earnings are generally related. Fourth, conservatism can reduce the political costs to standard setters and regulators from criticisms if firms overstate income or net assets. Watts (2003b) argues that empirical evidence mostly supports contracting and litigation explanations of conservatism. Kothari et al. (2010) further argue that conditional conservatism is a response to the demand for credible financial information from shareholders and debt holders.

The literature also makes a critical distinction between unconditional conservatism and conditional conservatism (Pope and Walker, 2003; Beaver and Ryan, 2005). On the one hand, unconditional conservatism - also known as ex ante or news-independent conservatism consists in continually understating the book value of net assets relatively to their economic value. This accounting bias toward reporting low earnings and book values of stockholders equity leads to higher (internally generated) un-booked goodwill and higher market-to-book 
ratio. Unconditional conservatism is a primary source of unrecorded goodwill, which also captures the present value of expected economic profits (e.g., rents, growth). Unconditional conservatism mechanisms include: routinely over-expensing, routinely expensing early or routinely deferring revenue recognition, independent of true economic income. Examples of unconditional conservatism include: expensing most costs related to internally developed intangibles; accelerated depreciation methods for property, plant, and equipment (usually driven by tax payments minimization incentives); historical cost accounting for positive net present value projects; systematic amortization of (purchased) goodwill. For instance, in Germany, creditor protection has been considered as the main factor explaining why pre-IFRS German firms "have engaged in unconditionally conservative practices such as charging future operating expenses against current period income" (Ball et al., 2008, 194). In France, rules to compute taxable income generated a strong incentive for accelerated depreciation methods. The various fair value options, the capitalization of development costs, or the change from goodwill amortization under domestic GAAP to impairment testing under IFRS are a few examples of an attempt to reduce unconditional conservatism.

On the other hand, conditional conservatism (also known as ex post or news-dependent conservatism) consists in writing down book values and decreasing income under sufficiently adverse circumstances. Conversely, book value is not written up when circumstances are favorable. Examples of conditional conservatism include asset impairments (for tangible and intangible fixed assets, financial instruments), accounting for inventories, and provisions.

Pope and Walker (2003) and Beaver and Ryan (2005) explain how the two forms of conservatisms are negatively related: lower ex ante unconditional conservatism is a condition for higher ex post conditional conservatism (see García Lara and Mora, 2004). Indeed, lower book values lower the threshold triggering conditional conservatism mechanisms, and vice versa. Unconditional conservatism 'constitutes a form of 'accounting slack' that pre-empts the application of conditional conservatism unless news is sufficiently bad to use up that slack" (Beaver and Ryan, 2005, 270). Pope and Walker (2003, 2) also shed light on this relation: "Ceteris paribus, when the proportion of market value accounted for by recognized assets is relatively high, a decrease in market value (bad news) is more likely to be attributable to assets currently recognized on the balance sheet." To exemplify this negative relation, taking the extreme case where an investment is completely expensed (e.g., most internally generated intangible assets) there is no possibility to book any impairment, even under extremely adverse circumstances, since there is no asset to impair. To be able to isolate 
the effect of IFRS on conditional conservatism, it is therefore critical to control for any changes in unconditional conservatism surrounding the adoption of IFRS.

There is general acceptance among standard setters that unconditional conservatism, as a deliberate understatement of asset values and earnings, is a form of 'bad' prudence (EFRAG et al., 2013, $\S 11$ ), while conditional conservatism has been recognized as a qualitative characteristic of financial reporting for decades at national or supra national levels by standard setters in Europe (EFRAG et al., 2013, § 1-2). Nevertheless, as noted by Holthausen (2009), the quality of financial reporting within each country is shaped by many forces and accounting standards are only one of them. Country-specific reporting incentives and institutional factors affect the quality of financial statement information and accounting standards alone are unlikely to mitigate these differences (Filip and Raffournier, 2011). Studies in the literature have documented various levels of conditional conservatism within countries in international settings (Ball et al., 2000; Ball et al., 2003; Watts, 2003a, 2003b; Gassen et al., 2006; Ball et al., 2008; Barth et al., 2008). These different country-specific levels of conditional conservatism are the result of an equilibrium in which accounting standards is one important factor. The introduction of IFRS in 2005 resulted in a major change to this factor which most likely resulted in firms responding differently - influenced by other country-specific institutional factors.

Up to recently, the IASB's and FASB's conceptual frameworks had a place for conservatism or 'prudence', a dimension of reliability that is one of the four principal qualitative characteristics of financial statements. To the surprise of many, the new joint conceptual framework of the IASB and FASB adopted in September 2010 but on the table since the early 2000s ("Chapter 1: Objectives of financial Reporting" and "Chapter 2: Qualitative characteristics") does not include conservatism or 'prudence' as a desirable quality of financial reporting (IASB, 2010). The IASB considers 'faithful representation' as a fundamental qualitative characteristic of financial information which implies a focus on completeness, neutrality, and freedom from errors. Examples of 'neutrality' under IFRS include greater use of fair values, impairment testing rather than amortization including the possibility to reverse prior impairments and stricter rules on how and when to book provisions. ${ }^{7}$ However, as already explained above, the form of 'prudence' that the IASB intended to eliminate from financial reporting is actually related to unconditional

\footnotetext{
${ }^{7}$ IAS 37 is said by many to curtail 'cookie jar reserves or provisions' quite prevalent in Continental Europe, (see Walton, 2011) for a discussion.
} 
conservatism, not conditional conservatism (see IASB, 2008, § BC2.21). ${ }^{8}$ From a conceptual perspective, the IASB framework and IFRS promote conditional conservatism while limiting unconditional conservatism. However, the actual degree of conditional and unconditional conservatism of financial reporting depends of the application (enforcement) of these principles.

Pope and Walker $(1999,60)$ also demonstrate how cost of capital affects empirical measures of conditional conservatism. In an analytical model, they assume market efficiency (and no growth) so that stock prices are equal to (1/r) times Permanent Earnings, where $r$ is the cost of capital. Permanent Earnings follow a random walk and Reported Earnings adjust Permanent Earnings by applying a certain degree of conditional conservatism to good vs. bad news (positive vs. negative shocks to previous Permanent Earnings). Under these assumptions, Pope and Walker (1999) show that cost of capital affects the coefficients of good vs. bad news of the Basu (1997) piecewise linear regression model, i.e., the responsiveness of earnings to positive and negative returns. Several studies document that the adoption of IFRS in 2005 had an effect on firm cost of capital (e.g., Karamanou and Nishiotis, 2009; Li, 2010; Daske et al., 2013). Therefore it is also important to control for a potential change in cost of capital surrounding the adoption of IFRS.

\section{LITERATURE REVIEW}

While Watts (2003b) surveys differences in conservatism in the US, we review time-series and cross-country studies in particular those concerning Europe. ${ }^{9}$ Ball et al. (2000) examine the effects of international institutional factors on the properties of accounting earnings. They find that accounting income in common-law countries (US, UK, Australia, Canada) is significantly more timely than in code-law countries (France, Germany, Japan) during the 1985-1995 period, due entirely to quicker incorporation of economic losses (income conservatism). Ball et al. (2000) suggest that UK income is less conservative than other common-law countries. However, Pope and Walker (1999) analyse differences in the timeliness of income recognition between the US and UK during the 1979-1996 period and conclude that apparent differences in conservatism between the US and UK are sensitive to the definition of earnings, in particular to the inclusion or the exclusion of extraordinary items in UK. Since according to UK GAAP there is greater latitude in the accounting for

\footnotetext{
${ }^{8}$ See also the excerpt in introduction from the exposure draft of the "Conceptual framework for financial reporting - Chapter 1 and 2" (IASB, 2008).

${ }^{9}$ See also Ryan (2006) for a survey of other types of conservatism studies.
} 
extraordinary items, their results suggest that UK firms recognize bad news faster than US firms but that they classify the bad news differently. Giner and Rees (2001), looking at a sample spanning from 1990 to 1998 find weak evidence that asymmetric recognition is stronger in the UK (common law) than in France (code-civil law) or Germany (code law). García Lara and Mora (2004) examine unconditional and conditional conservatisms in eight European countries (UK, Germany, France, Switzerland, the Netherlands, Italy, Spain and Belgium) and show that conditional conservatism practices are only marginally different between countries. However, they document that unconditional conservatism is greater in continental Europe and that there is a negative association between unconditional conservatism and conditional conservatism.

Raonic et al. (2004) further examine a sample of European firms from 1987-1999. They conclude that conservatism and timeliness are present and increasing regardless of the legal tradition while the importance of the equity markets jointly with the level of enforcement can explain some differences. Bushman and Piotroski (2006) examine the joint impact of legal system, securities law, political economy and tax regime on the level of asymmetric timeliness in 38 countries over the period of 1992 to 2001. They find greater conservatism in countries with high quality judicial systems after controlling for legal origin. Moreover, they find a similar result for countries with strong public enforcement from securities law but no impact from private enforcement aspects. They also show that managers adjust their financial reporting to the level of involvement of the state. Common law countries with low state involvement and civil law countries with greater state involvement exhibit greater conservatism. However, they find mixed and inconclusive results as to the impact of financial architecture and tax regime. Bushman et al. (2011) examine the impact of country specific conditional conservatism on capital allocation and find that investment responses to declining opportunities increase with conservatism, but not for increasing investment opportunities.

Gassen et al. (2006) examine 23 developed equity markets over the 1990-2003 period and show that cross-country differences in conditional conservatism are influenced by the effects of other accounting properties, mostly income smoothing and to a lesser extent unconditional conservatism. Gaio (2010) examines the relative importance of firm, industry and country characteristics in 38 countries over a similar time window ranging from 1990 to 2003 in explaining aggregate earnings quality based on many attributes including conservatism. 
None of the above studies covers the period following the mandatory adoption of IFRS by European countries in 2005. While there have been numerous country-specific and crosscountry studies on the impact of mandatory IFRS adoption on various dimensions of accounting quality such as value relevance (e.g., Barth et al., 2008; Capkun et al., 2008; Filip, 2010; Tsalavoutas et al., 2012) or earnings management (Barth et al., 2008) and other economic consequences, for example on the cost of capital (e.g., Daske et al., 2008; Li, 2010), there are only a couple of papers analysing the impact of IFRS on accounting conservatism.

Ahmed et al. (2013) examine the effect of the adoption of IFRS in 20 countries around the world on various measures of accounting quality, namely income smoothing, reporting aggressiveness, and the likelihood to meet or beat earnings benchmark. Ahmed et al. (2013), considering the methodological issues related to the Basu (1997) measure, use the asymmetric timeliness measure "only to supplement [their] accruals testing providing evidence on changes in aggressiveness of financial reporting after IFRS adoption and to compare [their] findings with prior work that has used timeliness of loss recognition measures" (p. 16). ${ }^{10}$ The authors find a reduction in the timeliness of loss recognition after 2005 only in countries with strong enforcement. Ahmed et al. (2013) highlight that the increase discretion and flexibility permitted by IFRS could prevent financial reporting quality to increase despite strong enforcement. Our study differs from Ahmed et al. (2013) in several important respects. First, we control for the potential effect of shifts in unconditional conservatism and cost of capital on conditional conservatism, whereas Ahmed et al. (2013) use a control group mainly composed of US and Japanese firms. Second, we explore several institutional factors explaining the change in conditional conservatism, whereas Ahmed et al. (2013) examine only the influence of the rule of law. Third, we attempt to identify an important mechanism explaining the decrease in conditional conservatism, namely inappropriate enforcement of impairment test.

Piot et al. (2010) examine conditional and unconditional conservatism around the IFRS voluntary and mandatory adoption and study the role of Big 4 auditors. Relative to the studies mentioned above, our focus is more specifically on European 2005 mandatory IFRS adopters and on country specific results. While our findings are consistent with the above cited studies (all report a decrease in conditional conservatism following the IFRS adoption), we contribute to the literature by explaining this decrease of accounting conservatism, controlling for shifts

\footnotetext{
${ }^{10}$ Patatoukas and Thomas (2011) argue that the Basu (1997) measure suffers from scale effects, whereas Ball et al. (2013) demonstrate that the measure is affected by a correlated omitted variable issue that can be corrected with 'standard' estimation procedures such as the Khan and Watts (2009) version of the Basu (1997) measure.
} 
of unconditional conservatism and cost of capital, with various institutional factors, and attempt to identify one important channel of the decrease in conditional conservatism.

\section{DEVELOPMENT OF HYPOTHESES}

\section{(i) Conservatism and Mandatory IFRS Adoption}

We argue that the switch to IFRS, a set of principle-based accounting standards oriented toward faithful representation of economic reality to inform capital providers, introduced accounting procedures intended to increase conditional conservatism, relatively to domestic GAAP. However, the actual level of conditional conservatism of financial reporting reached after the adoption of IFRS in 2005 depends on many institutional factors shaping the incentives to apply the principles introduced by IFRS. It is difficult to conjecture on the effect of the mandatory adoption of IFRS introducing these principles and of particular institutional factors present in each country which vary on many dimensions. Therefore we state our main hypothesis in the alternative but non-directional form.

H1: The mandatory adoption of IFRS in 2005 led to a change in the degree of conditional conservatism of financial reporting.

\section{(ii) The effect of institutional factors on conditional conservatism}

As noted above, (Watts, 2003a) suggests four explanations for conservatism: contracting, shareholder litigation, taxation and financial reporting standard/regulation. We look at crosscountry variation in conservatism with respect to institutional factors and examine whether these factors influence the change in the degree of conditional conservatism. More specifically, we examine differences in enforcement, corporate governance, and clusters combining these with the level of investor protection, nature of the economy and development of stock markets.

Strong legal rules are a necessary condition to guarantee that the rights of shareholders are protected, but not a sufficient one. Legal rules may remain ineffective without proper enforcement (Burgstahler et al., 2006). Furthermore, a solid system of legal enforcement can also substitute for weak rules since active and well-functioning courts can rescue investors abused by managers (la Porta et al., 1998). The influence of law enforcement is supported by numerous studies dealing with various aspects of accounting quality. Bushman and Piotroski (2006) for example show that firms in countries with strong public law enforcement slow the 
recognition of good news in reported earnings relative to firms in countries with weak public law enforcement. Daske et al. (2008) document that the increase in liquidity and equity valuations following the mandatory adoption of IFRS is restricted to countries with strict enforcement regimes. Consistent with these findings, DeFond et al. (2007) report that high quality earnings combined with strong law enforcement strengthen the market reactions to earnings announcements.

La Porta et al. (1998) proposed several proxies for the quality of law enforcement. The measure we use is from Leuz et al. (2003) and obtained by averaging three of them in a single measure (ENF), which they used as a control variable to test whether investor protection constrains earnings management.

However, law is not the only source of protection for investors. Compliance with corporate governance recommendations may also reduce the level of expropriation by insiders (Renders and Gaeremynck, 2007). Durnev and Kim (2005) in particular show that firms with better governance are valued higher on stock markets, especially where legal investor protection is weak, which leads them to conclude that firms adapt to poor legal environments by establishing efficient governance practices. There is a growing body of research on the influence of corporate governance characteristics on accounting quality.

Variables aimed at measuring the quality of legal enforcement, such as those developed by La Porta et al. (1998), cannot capture the extent of corporate governance rules because they don't take into account extra-legal regulations. Institutional Shareholders Services provides Corporate Governance Quotient for a large sample of international firms. Aggarwall et al. (2009) use it to construct an index of corporate governance quality at the national level. GOV7 focuses on seven individual governance characteristics that have received the most attention in the academic literature.

Leuz et al. (2003) perform a cluster analysis which groups countries based on similar legal and institutional characteristics into three groups: group \#1 includes countries with outsider economies and large stock markets, dispersed ownership and strong investor rights and legal enforcement (Great Britain and Norway); group \#2 have insider economies and less developed stock markets, concentrated ownership, weak investor rights but strong enforcement (Austria, Belgium, Denmark, Finland, France, Germany, Ireland, Netherlands, Sweden, and Switzerland); group \#3 consists of insider economies with weak enforcement (Greece, Italy, Portugal, and Spain). 
Beyond the discussions above, Bona-Sánchez et al. (2011) suggest that more insider economies should be less conservative since less minority shareholders and better monitoring of management. The main institutional difference between group \#2 and group \#3 is the level of enforcement. Therefore, we expect that the adoption of IFRS affected conservatism differently in these two groups.

All these institutional factors shape the incentives to apply conditional conservatism mechanisms under IFRS. As it is a priori unclear if they would interact with the application of IFRS in 2005, we state our second assumption in the alternative but unsigned form.

H2: Changes in the degree of conditional conservatism of financial reporting after the adoption of IFRS are associated with institutional factors.

\section{(iii) The effect of impairment test on conditional conservatism}

The implementation of conservatism mechanisms under IFRS is different from domestic GAAP as it requires subjective judgment from managers. Impairment tests illustrate the higher level of subjectivity of IFRS. Impairment tests ensure that assets are not carried at more than their economic value, also known as the recoverable value (IASB, 2004). IFRS require that an impairment loss should be recognised in earnings whenever the recoverable amount is below the carrying amount (IAS $36 \S 59$ ). The recoverable amount is the greater of 'value-in-use' (present value of firm-specific expected future cash flows) or 'fair value less costs to sell' (computed with observable market data). Recoverable value for intangible assets is typically based on 'value-in-use'. The implementation of impairment tests usually rely on valuation models and involves 'significant judgment' from managers (Petersen and Plenborg, 2010). Agency theory predicts that unverifiable discretion can be used opportunistically by managers (Ramanna, 2008). Ramanna (2008), Li and Sloan (2011) and Ramanna and Watts (2012) demonstrate that impairments tend to be manipulated by managers because the procedure relies on unverifiable fair value estimates. Asset impairments tend to be delayed and/or avoided. Ceteris paribus, lagged and delayed impairment reduce the level of conditional conservatism.

In Europe, the AMF (“Autorité des Marchés Financiers”), the French counterpart of the US Securities and Exchange Commission, in a report made November 4, 2009 made several recommendations to urge companies to comply with the requirements of IAS 36. In a report on financial reporting of the French CAC 40 (top 40 companies listed in Paris) issued in 2010, the audit firm PwC also noticed the disparity of IFRS reporting practices. Petersen and 
Plenborg (2010, 420) document inconsistencies with impairment principles in Denmark. In Germany, responding to auditors' difficulties to conduct valuations, the profession issued and revised 'valuation standards' (IDW, 2005, 2008) in order, among other things, to help auditors apply IFRS. The type of assets most subject to subjectivity are intangible assets with indefinite useful life (e.g., goodwill, most brands) for which impairment tests are required to be done at least once a year and rely on unverifiable fair value estimates that depend on future performance. If inappropriate enforcement of impairment tests drives the change in conditional conservatism, firm carrying relatively more intangibles in their balance sheet would experience a greater change in the degree of conditional conservatism. We state our third hypothesis in an unsigned alternative form.

H3: Firms carrying intangibles in their balance sheet experience a larger change in the degree of conditional conservatism of financial reporting than other firms after the adoption of IFRS.

\section{EMPIRICAL MODEL, SAMPLING AND DATA COLLECTION}

Consistent with prior research, the asymmetric treatment of losses and gains is captured by the linear regression of accounting earnings on stock returns, i.e. the Basu (1997) model:

$\mathrm{NI}_{\text {it }}=\alpha_{1}+\alpha_{2} \mathrm{BN}_{\mathrm{it}}+\alpha_{3} \mathrm{R}_{\mathrm{it}}+\alpha_{4} \mathrm{BN}_{\mathrm{it}} \mathrm{R}_{\mathrm{it}}+\zeta_{\text {it }}$

where:

$\mathrm{R}_{\mathrm{it}} \quad$ market return of firm $\mathrm{i}$ in year $\mathrm{t}$, net of dividends and capital contributions;

$\mathrm{NI}_{\mathrm{it}} \quad$ net income of firm $\mathrm{i}$ in year $\mathrm{t}$, scaled by beginning of the period market value;

$\mathrm{BN}_{\mathrm{it}} \quad$ is a dummy variable equal to 1 if $\mathrm{R}_{\mathrm{it}}$ is negative and 0 otherwise.

Coefficient $\alpha_{3}$ on the market return measures the timeliness of gain recognition or the responsiveness of earnings to good news, while the sum of $\alpha_{3}+\alpha_{4}$ is measuring the timely loss recognition or the responsiveness of earnings to bad news. According to Pope and Walker (1999), the focus is on the $\alpha_{4}$ coefficient of the product of market return by the return dummy which measures incremental timeliness of loss recognition. A positive and significant coefficient implies asymmetric timely loss recognition and therefore conditional conservative accounting (Pope and Walker, 1999; Ball et al., 2000). A higher coefficient denotes more incremental timely loss recognition and therefore more conservative accounting. 


\section{(i) Research design}

In order to take into account the impact of IFRS, we transform the classic Basu (1997) model by adding another dummy variable (i.e. IFRS) and its interaction effects. This approach is inspired by Ball and Shivakumar (2005) who modify the model to allow for differences between subsamples. Therefore equation (0) becomes:

where:

$$
\begin{aligned}
\mathrm{NI}_{\mathrm{it}}= & \alpha_{1}+\alpha_{2} \mathrm{BN}_{\mathrm{it}}+\alpha_{3} \mathrm{R}_{\mathrm{it}}+\alpha_{4} \mathrm{BN}_{\mathrm{it}} \mathrm{R}_{\mathrm{it}}+ \\
& +\alpha_{5} \mathrm{IFRS}_{\mathrm{it}}+\alpha_{6} \mathrm{IFRS}_{\mathrm{it}} \mathrm{BN}_{\mathrm{it}}+\alpha_{7} \mathrm{IFRS}_{\mathrm{it}} \mathrm{R}_{\mathrm{it}}+\alpha_{8} \mathrm{IFRS}_{\mathrm{it}} \mathrm{BN}_{\mathrm{it}} \mathrm{R}_{\mathrm{it}}+\zeta_{\mathrm{it}}
\end{aligned}
$$

where:

IFRS $_{\text {it }}$ is a dummy variable equal to 1 if the year is 2005,2006 , or 2007 , and 0 otherwise;

All other variables are defined above.

In equation (1), coefficient $\alpha_{3}$ measures the responsiveness of earnings to good news before IFRS adoption, while the sum $\alpha_{3}+\alpha_{7}$ is measuring the responsiveness of earnings to good news after IFRS adoption. A positive significant coefficient $\alpha_{7}$ implies incremental responsiveness of earnings to good news after IFRS adoption. The responsiveness of earnings to bad news before the IFRS adoption is measured by the sum $\alpha_{3}+\alpha_{4}$, while the responsiveness of earnings to bad news after IFRS adoption is measured by the sum $\alpha_{3}+\alpha_{4}+$ $\alpha_{7}+\alpha_{8}$. An incremental timeliness of loss recognition significantly higher for the post-IFRS period would imply a positive and significant coefficient $\alpha_{8}$. A negative coefficient $\alpha_{8}$ denotes less timely loss recognition after the IFRS adoption, i.e., less conservative accounting. We offer no prediction for the intercept coefficients $\alpha_{1}, \alpha_{2}, \alpha_{5}$, and $\alpha_{6}$ measuring unconditional conservatism.

Our second measure of conditional conservatism takes into account a set of firm characteristics that previous research has shown to influence conditional conservatism. We follow Khan and Watts (2009) and use three variables - size, market to book ratio and leverage - as summary measures of the four Watts (2003a) factors (contracting, litigation, taxation, and regulation) that drive conservatism. The regression model (1) becomes:

$$
\begin{aligned}
\mathrm{NI}_{\mathrm{it}}= & \alpha_{1}+\alpha_{2} \mathrm{BN}_{\mathrm{it}}+\alpha_{3} \mathrm{R}_{\mathrm{it}}+\alpha_{4} \mathrm{BN}_{\mathrm{it}} \mathrm{R}_{\mathrm{it}}+ \\
& +\alpha_{5} \mathrm{IFRS}_{\mathrm{it}}+\alpha_{6} \mathrm{IFRS}_{\mathrm{it}} \mathrm{BN}_{\mathrm{it}}+\alpha_{7} \mathrm{IFRS}_{\mathrm{it}} \mathrm{R}_{\mathrm{it}}+\alpha_{8} \mathrm{IFRS}_{\mathrm{it}} \mathrm{BN}_{\mathrm{it}} \mathrm{R}_{\mathrm{it}}+ \\
& +\alpha_{9} \mathrm{SIZE}_{\mathrm{it}}+\alpha_{10} \mathrm{SIZE}_{\mathrm{it}} \mathrm{BN}_{\mathrm{it}}+\alpha_{11} \mathrm{SIZE}_{\mathrm{it}} \mathrm{R}_{\mathrm{it}}+\alpha_{12} \mathrm{SIZE}_{\mathrm{it}} \mathrm{BN}_{\mathrm{it}} \mathrm{R}_{\mathrm{it}}+
\end{aligned}
$$




$$
\begin{aligned}
& +\alpha_{13} \mathrm{MB}_{\mathrm{it}}+\alpha_{14} \mathrm{MB}_{\mathrm{it}} \mathrm{BN}_{\mathrm{it}}+\alpha_{15} \mathrm{MB}_{\mathrm{it}} \mathrm{R}_{\mathrm{it}}+\alpha_{16} \mathrm{MB}_{\mathrm{it}} \mathrm{BN}_{\mathrm{it}} \mathrm{R}_{\mathrm{it}}+ \\
& +\alpha_{17} \mathrm{LEV}_{\mathrm{it}}+\alpha_{18} \mathrm{LEV}_{\mathrm{it}} \mathrm{BN}_{\mathrm{it}}+\alpha_{19} \mathrm{LEV}_{\mathrm{it}} \mathrm{R}_{\mathrm{it}}+\alpha_{20} \mathrm{LEV}_{\mathrm{it}} \mathrm{BN}_{\mathrm{it}} \mathrm{R}_{\mathrm{it}}+\zeta_{\mathrm{it}}
\end{aligned}
$$

where:

SIZE $_{\text {it }} \log$ of the market value of firm $i$ at the end of the year $t$;

$\mathrm{MB}_{\text {it }}$ market to book ratio of firm $\mathrm{i}$ at the end of the year $\mathrm{t}$;

$\mathrm{LEV}_{\mathrm{it}}$ leverage of firm $\mathrm{i}$ at the end of the year $\mathrm{t}$, defined as total debt scaled by market value;

All other variables are defined above.

Under this specification, conditional conservatism is measured as the sum of the coefficients $\alpha_{4}+\alpha_{8}+\alpha_{12}+\alpha_{16}+\alpha_{20}$. Similar to model (1), the impact of the mandatory IFRS adoption on conditional conservatism is captured by the coefficient $\alpha_{8}$.

Our third empirical specification measuring the level of conditional conservatism controls for the effects of shifts in unconditional conservatism and cost of capital. Pope and Walker (2003) and Beaver and Ryan (2005) explain that conditional and unconditional conservatism are negatively related. Therefore it is essential to control for possible changes in the level of unconditional conservatism. In order to capture unconditional conservatism, we use the residual of annual and country cross sectional regressions ${ }^{11}$ of the market-to-book ratio of equity to several variables that previous research (Roychowdhury and Watts, 2007; Piot et al., 2011) has shown to be correlated to the dependent variable (i.e. market returns, level of intangibles, net value of property plant and equipment, capital expenditures, change in sales, return on equity, volatility, leverage and size). Market-to-book ratio is influenced by two factors: (1) the unverifiable (un-booked) increases in value of separable assets in place (true unconditional conservatism), and (2) the expected value of economic profits (e.g., synergies between assets in place, growth, rents) (Roychowdhury and Watts, 2007).

\footnotetext{
${ }^{11}$ The regression used for each country and year to determine the level of unconditional conservatism is: $\mathrm{MB}_{\text {it }}=\beta_{1}+\beta_{2} \mathrm{R}_{\mathrm{it}}+\beta_{3} \mathrm{INTAN}_{\mathrm{it}}+\beta_{4} \mathrm{PPEN}_{\mathrm{it}}+\beta_{5} \mathrm{CAPEX}_{\mathrm{it}}+\beta_{6} \Delta \mathrm{SALES}_{\mathrm{it}}+\beta_{7} \mathrm{ROE}_{\mathrm{it}}+\beta_{8} \mathrm{VOLAT}_{\text {it }}+\beta_{9} \mathrm{LEV}_{\text {it }}+$ $+\beta_{10} \mathrm{SIZE}_{\mathrm{it}}+\varsigma$ where:

INTAN $_{\text {it }}$ intangible assets of firm $\mathrm{i}$ at the end of the year $\mathrm{t}$, scaled by total assets;

PPEN $_{i t} \quad$ net value of property plant and equipment of firm $\mathrm{i}$ at the end of the year $\mathrm{t}$, scaled by total assets;

CAPEX $_{\text {it }} \quad$ capital expenditures firm $i$ at the end of the year $t$, scaled by total assets;

$\triangle$ SALES $_{\text {it }} \quad$ percentage change in sales of firm $\mathrm{i}$ in year $\mathrm{t}$;

$\mathrm{ROE}_{\mathrm{it}} \quad$ net income firm $\mathrm{i}$ in year $\mathrm{t}$, scaled by equity;

VOLAT $_{\text {it }}$ price volatility of the share of the firm i in year $t$;

All other variables are defined above.
} 
Therefore, we adjust market-to-book for expected growth and take the residuals as a proxy for unconditional conservatism.

Pope and Walker (1999) show that conditional conservatism is also related to the cost of capital, while various studies have demonstrated that cost of capital was affected by the adoption of IFRS (Karamanou and Nishiotis, 2009; Li, 2010; Daske et al., 2013). As a proxy for the cost of capital we use the beta coefficient for each firm-year observation. The regression model (1) becomes:

$$
\begin{aligned}
\mathrm{NI}_{\mathrm{it}}= & \alpha_{1}+\alpha_{2} \mathrm{BN}_{\mathrm{it}}+\alpha_{3} \mathrm{R}_{\mathrm{it}}+\alpha_{4} \mathrm{BN}_{\mathrm{it}} \mathrm{R}_{\mathrm{it}}+ \\
& +\alpha_{5} \mathrm{IFRS}_{\mathrm{it}}+\alpha_{6} \mathrm{IFRS}_{\mathrm{it}} \mathrm{BN}_{\mathrm{it}}+\alpha_{7} \mathrm{IFRS}_{\mathrm{it}} \mathrm{R}_{\mathrm{it}}+\alpha_{8} \mathrm{IFRS}_{\mathrm{it}} \mathrm{BN}_{\mathrm{it}} \mathrm{R}_{\mathrm{it}}+ \\
& +\alpha_{21} \mathrm{BETA}_{\mathrm{it}}+\alpha_{22} \mathrm{BETA}_{\mathrm{it}} \mathrm{BN}_{\mathrm{it}}+\alpha_{23} \mathrm{BETA}_{\mathrm{it}} \mathrm{R}_{\mathrm{it}}+\alpha_{24} \mathrm{BETA}_{\mathrm{it}} \mathrm{BN}_{\mathrm{it}} \mathrm{R}_{\mathrm{it}}+ \\
& +\alpha_{25} \mathrm{UCC}_{\mathrm{it}}+\alpha_{26} \mathrm{UCC}_{\mathrm{it}} \mathrm{BN}_{\mathrm{it}}+\alpha_{27} \mathrm{UCC}_{\mathrm{it}} \mathrm{R}_{\mathrm{it}}+\alpha_{28} \mathrm{UCC}_{\mathrm{it}} \mathrm{BN}_{\mathrm{it}} \mathrm{R}_{\mathrm{it}}+\zeta_{\mathrm{it}}
\end{aligned}
$$

where:

BETA $_{i t} \quad$ beta coefficient of firm $i$ in year $t$;

$\mathrm{UCC}_{\mathrm{it}} \quad$ measure of unconditional conservatism of firm $\mathrm{i}$ in year $\mathrm{t}$;

All other variables are defined above.

Similar to the previous models, the impact of the mandatory IFRS adoption on conditional conservatism is captured by the coefficient $\alpha_{8}$. The coefficient $\alpha_{24}$ is capturing the effect of higher risk firms on conditional conservatism, while we predict $\alpha_{28}$ to be negative, consistent with more unconditional conservative firms having lower asymmetric timeliness of earnings.

Equation (4) represents the expanded version of the Basu (1997) model and includes all control variables that might impact the demand for conservatism:

$$
\begin{aligned}
\mathrm{NI}_{\mathrm{it}}= & \alpha_{1}+\alpha_{2} \mathrm{BN}_{\mathrm{it}}+\alpha_{3} \mathrm{R}_{\mathrm{it}}+\alpha_{4} \mathrm{BN}_{\mathrm{it}} \mathrm{R}_{\mathrm{it}}+ \\
& +\alpha_{5} \mathrm{IFRS}_{\mathrm{it}}+\alpha_{6} \mathrm{IFRS}_{\mathrm{it}} \mathrm{BN}_{\mathrm{it}}+\alpha_{7} \mathrm{IFRS}_{\mathrm{it}} \mathrm{R}_{\mathrm{it}}+\alpha_{8} \mathrm{IFRS}_{\mathrm{it}} \mathrm{BN}_{\mathrm{it}} \mathrm{R}_{\mathrm{it}}+ \\
& +\alpha_{9} \mathrm{SIZE}_{\mathrm{it}}+\alpha_{10} \mathrm{SIZE}_{\mathrm{it}} \mathrm{BN}_{\mathrm{it}}+\alpha_{11} \mathrm{SIZE}_{\mathrm{it}} \mathrm{R}_{\mathrm{it}}+\alpha_{12} \mathrm{SIZE}_{\mathrm{it}} \mathrm{BN}_{\mathrm{it}} \mathrm{R}_{\mathrm{it}}+ \\
& +\alpha_{13} \mathrm{MB}_{\mathrm{it}}+\alpha_{14} \mathrm{MB}_{\mathrm{it}} \mathrm{BN}_{\mathrm{it}}+\alpha_{15} \mathrm{MB}_{\mathrm{it}} \mathrm{R}_{\mathrm{it}}+\alpha_{16} \mathrm{MB}_{\mathrm{it}} \mathrm{BN}_{\mathrm{it}} \mathrm{R}_{\mathrm{it}}+ \\
& +\alpha_{17} \mathrm{LEV}_{\mathrm{it}}+\alpha_{18} \mathrm{LEV}_{\mathrm{it}} \mathrm{BN}_{\mathrm{it}}+\alpha_{19} \mathrm{LEV}_{\mathrm{it}} \mathrm{R}_{\mathrm{it}}+\alpha_{20} \mathrm{LEV}_{\mathrm{it}} \mathrm{BN}_{\mathrm{it}} \mathrm{R}_{\mathrm{it}}+ \\
& +\alpha_{21} \mathrm{BETA}_{\mathrm{it}}+\alpha_{22} \mathrm{BETA}_{\mathrm{it}} \mathrm{BN}_{\mathrm{it}}+\alpha_{23} \mathrm{BETA}_{\mathrm{it}} \mathrm{R}_{\mathrm{it}}+\alpha_{24} \mathrm{BETA}_{\mathrm{it}} \mathrm{BN}_{\mathrm{it}} \mathrm{R}_{\mathrm{it}}+ \\
& +\alpha_{25} \mathrm{UCC}_{\mathrm{it}}+\alpha_{26} \mathrm{UCC}_{\mathrm{it}} \mathrm{BN}_{\mathrm{it}}+\alpha_{27} \mathrm{UCC}_{\mathrm{it}} \mathrm{R}_{\mathrm{it}}+\alpha_{28} \mathrm{UCC}_{\mathrm{it}} \mathrm{BN}_{\mathrm{it}} \mathrm{R}_{\mathrm{it}}+\zeta_{\mathrm{it}}
\end{aligned}
$$

All variables are defined above. 
Finally we use cluster analyses based on several institutional dimensions well documented in the literature. In order to take into account the differences in the level of conditional conservatism between the different classification schemes, we further introduce another dummy variable that takes the value 1 if the observation belongs to the specific classification scheme, and zero otherwise. Therefore, equation (4) becomes:

$$
\begin{aligned}
\mathrm{NI}_{\mathrm{it}}= & \alpha_{1}+\alpha_{2} \mathrm{BN}_{\mathrm{it}}+\alpha_{3} \mathrm{R}_{\mathrm{it}}+\alpha_{4} \mathrm{BN}_{\mathrm{it}} \mathrm{R}_{\mathrm{it}}+ \\
& +\alpha_{5} \mathrm{IFRS}_{\mathrm{it}}+\alpha_{6} \mathrm{IFRS}_{\mathrm{it}} \mathrm{BN}_{\mathrm{it}}+\alpha_{7} \mathrm{IFRS}_{\mathrm{it}} \mathrm{R}_{\mathrm{it}}+\alpha_{8} \mathrm{IFRS}_{\mathrm{it}} \mathrm{BN}_{\mathrm{it}} \mathrm{R}_{\mathrm{it}}+ \\
& +\alpha_{9} \mathrm{SIZE}_{\mathrm{it}}+\alpha_{10} \mathrm{SIZE}_{\mathrm{it}} \mathrm{BN}_{\mathrm{it}}+\alpha_{11} \mathrm{SIZE}_{\mathrm{it}} \mathrm{R}_{\mathrm{it}}+\alpha_{12} \mathrm{SIZE}_{\mathrm{it}} \mathrm{BN}_{\mathrm{it}} \mathrm{R}_{\mathrm{it}}+ \\
& +\alpha_{13} \mathrm{MB}_{\mathrm{it}}+\alpha_{14} \mathrm{MB}_{\mathrm{it}} \mathrm{BN}_{\mathrm{it}}+\alpha_{15} \mathrm{MB}_{\mathrm{it}} \mathrm{R}_{\mathrm{it}}+\alpha_{16} \mathrm{MB}_{\mathrm{it}} \mathrm{BN}_{\mathrm{it}} \mathrm{R}_{\mathrm{it}}+ \\
& +\alpha_{17} \mathrm{LEV}_{\mathrm{it}}+\alpha_{18} \mathrm{LEV}_{\mathrm{it}} \mathrm{BN}_{\mathrm{it}}+\alpha_{19} \mathrm{LEV}_{\mathrm{it}} \mathrm{R}_{\mathrm{it}}+\alpha_{20} \mathrm{LEV}_{\mathrm{it}} \mathrm{BN}_{\mathrm{it}} \mathrm{R}_{\mathrm{it}}+ \\
& +\alpha_{21} \mathrm{BETA}_{\mathrm{it}}+\alpha_{22} \mathrm{BETA}_{\mathrm{it}} \mathrm{BN}_{\mathrm{it}}+\alpha_{23} \mathrm{BETA}_{\mathrm{it}} \mathrm{R}_{\mathrm{it}}+\alpha_{24} \mathrm{BETA}_{\mathrm{it}} \mathrm{BN}_{\mathrm{it}} \mathrm{R}_{\mathrm{it}}+ \\
& +\alpha_{25} \mathrm{UCC}_{\mathrm{it}}+\alpha_{26} \mathrm{UCC}_{\mathrm{it}} \mathrm{BN}_{\mathrm{it}}+\alpha_{27} \mathrm{UCC}_{\mathrm{it}} \mathrm{R}_{\mathrm{it}}+\alpha_{28} \mathrm{UCC}_{\mathrm{it}} \mathrm{BN}_{\mathrm{it}} \mathrm{R}_{\mathrm{it}}+ \\
& +\alpha_{29} \mathrm{IF}_{\mathrm{it}}+\alpha_{30} \mathrm{BN}_{\mathrm{it}} \mathrm{IF}_{\mathrm{it}}+\alpha_{31} \mathrm{R}_{\mathrm{it}} \mathrm{IF}_{\mathrm{it}}+\alpha_{32} \mathrm{BN}_{\mathrm{it}} \mathrm{R}_{\mathrm{it}} \mathrm{IF} \mathrm{F}_{\mathrm{it}}+ \\
& +\alpha_{33} \mathrm{IFRS}_{\mathrm{it}} \mathrm{IFit}+\alpha_{34} \mathrm{IFRS}_{\mathrm{it}} \mathrm{BN}_{\mathrm{it}} \mathrm{IF}_{\mathrm{it}}+\alpha_{35} \mathrm{IFRS}_{\mathrm{it}} \mathrm{R}_{\mathrm{it}} \mathrm{IF}_{\mathrm{it}}+\alpha_{36} \mathrm{IFRS}_{\mathrm{it}} \mathrm{BN}_{\mathrm{it}} \mathrm{R}_{\mathrm{it}} \mathrm{IF}_{\mathrm{it}}+\zeta_{\mathrm{it}}
\end{aligned}
$$

where:

$\mathrm{IF}_{\text {it }}$ is a dummy variable equal to 1 if a firm belongs to the specific group and 0 otherwise;

All other variables are defined above.

In model (5), the sum of the coefficients $\alpha_{4}+\alpha_{12}+\alpha_{16}+\alpha_{20}+\alpha_{24}+\alpha_{28}$ is measuring the level of conditional conservatism before IFRS adoption for the classification scheme 0 , while $\alpha_{4}+\alpha_{8}+\alpha_{12}+\alpha_{16}+\alpha_{20}+\alpha_{24}+\alpha_{28}$ the measure after IFRS adoption. Similarly, the sum $\alpha_{4}+$ $\alpha_{12}+\alpha_{16}+\alpha_{20}+\alpha_{24}+\alpha_{28}+\alpha_{32}$ is measuring the level of accounting conservatism before IFRS adoption for the classification scheme 1, while $\alpha_{4}+\alpha_{8}+\alpha_{12}+\alpha_{16}+\alpha_{20}+\alpha_{24}+\alpha_{28}+\alpha_{32}+\alpha_{36}$ the measure after IFRS adoption. Coefficient $\alpha_{8}\left(\alpha_{8}+\alpha_{36}\right)$ is capturing the impact of IFRS on accounting conservatism for the classification scheme 0 (1). The test of differences is as follows:

\begin{tabular}{lllll} 
& $\mathrm{IF}_{\text {it }}=0$ & $\mathrm{IF}_{\text {it }}=1$ & $\Delta$ \\
$\mathrm{IFRS}_{\text {it }}=0$ & $\alpha_{4}+\alpha_{12}+\alpha_{16}+\alpha_{20}+\alpha_{24}+\alpha_{28}$ & $\alpha_{4}+\alpha_{12}+\alpha_{16}+\alpha_{20}+\alpha_{24}+\alpha_{28}+\alpha_{32}$ & $\alpha_{32}$ \\
$\mathrm{IFRS}_{\text {it }}=1$ & $\alpha_{4}+\alpha_{8}+\alpha_{12}+\alpha_{16}+\alpha_{20}+\alpha_{24}+\alpha_{28}$ & $\alpha_{4}+\alpha_{8}+\alpha_{12}+\alpha_{16}+\alpha_{20}+\alpha_{24}+\alpha_{28}+\alpha_{32}+\alpha_{36}$ & $\alpha_{32}+\alpha_{36}$ \\
\cline { 2 - 4 }$\Delta$ & $\alpha_{8}$ & $\alpha_{8}+\alpha_{36}$ & $\alpha_{36}$
\end{tabular}




\section{(ii) Sampling and data collection}

Regulation No. 1606/2002 of the European Parliament requiring all public firms to prepare consolidated financial statements on the basis of IFRS was issued in 2002, at a time when the EU was composed of 15 member states. In 2004, ten other countries joined the EU, followed by Romania and Bulgaria in 2007. To avoid ambiguity, our study focuses on the 15 "early" EU member states. Because Norway and Switzerland issued similar regulations, they are also included in our sample. Luxembourg was dropped from the sample because of an insufficient number of observations.

Panel A of Table 1 describes the sampling and data collection process. Our initial sample comes from the Worldscope database consisting of 8,379 active public firms from the 16 European countries. Because banks, insurance companies and other financial institutions (WS.PrimarySICCode 43xx) follow specific reporting regulations, they are deleted from the sample (2,554 firms). As our study focuses on 2005 IFRS adopters, firms that followed international accounting standards before 2005 (WS.AcctStandardsFollowed 02 or 23) and firms that followed other than IFRS accounting standards after 2005 are deleted from the sample. In order to reduce the possible risk of bias, all firms where this data is not available are also deleted from the sample. This leads to a sample of 2,796 firms adopting IFRS in 2005 (2005 IFRS adopters).

\section{INSERT TABLE 1 ABOUT HERE}

Next we collect the accounting and market data from Worldscope database ${ }^{12}$ for the period 2002 to 2007. To avoid ambiguity, post-2007 years were not included in the present analyses since market data are strongly affected by the financial crisis and this could raise questions about the validity of the results. Data was not available for 9,293 firm-year observations and another 232 observations were dropped from the sample due to negative equity or negative total assets. Or final sample consists therefore of 7,251 firm-year observations.

Panel B of Table 1 provides the distribution of the observations per country. As usual in studies on European capital markets, most observations are from France $(1,263)$ and Great

\footnotetext{
${ }^{12}$ We also use Datastream in order to collect the beta coefficient that is not available in Worldscope.
} 
Britain (1,232), while the lowest number of observations is from Austria (74) ${ }^{13}$. In order to mitigate the effects of outliers on our inferences, we winsorize all continuous variables used in our regressions at 5\% (Barth et al., 2011). ${ }^{14}$ Panel $\mathrm{C}$ of Table 1 presents some descriptive statistics for the main variables used in the empirical models. A few observations are noteworthy. The average (median) market-to-book and beta are 2.330 (1.843) and 0.779 (0.660) respectively. Average (median) leverage is $56.4 \%$ (30.2\%). The average (median) level of intangibles to total assets is $14.4 \%(8.1 \%)$.

\section{EMPIRICAL FINDINGS}

\section{(i) Overall effect of the mandatory adoption of IFRS on conditional conservatism}

In the Basu (1997) model of conservatism, quality accounting earnings are deemed to reflect bad news more quickly than good news, while market returns capture both good news and bad news simultaneously. The first column of table 2 reports the results of the regression from model (1) for the overall sample. The adjusted $\mathrm{R}^{2}$ is 0.157 and is consistent with previous value relevance studies conducted in Europe. ${ }^{15}$ Turning to the incremental timeliness of loss recognition (i.e. conditional conservatism), $\left(\mathrm{BN}_{\mathrm{it}} \mathrm{R}_{\mathrm{it}}\right)$ in the pre-IFRS period is positive and significant $\left(0.278^{* * *}\right)$. However, the change to IFRS $\left(\mathrm{BN}_{\mathrm{it}} \mathrm{R}_{\mathrm{it}} \mathrm{IFRS} \mathrm{S}_{\mathrm{it}}\right)$ leads to a significant reduction in conditional conservatism $\left(-0.135^{* * *}\right)$.

\section{INSERT TABLE 2 ABOUT HERE}

Model (2) is controlling for a set of firm characteristics that previous research has shown to influence conditional conservatism. Even after controlling for size, market-to-book ratio and leverage as in Khan and Watts (2009), the impact of IFRS on the timeliness of loss recognition remains negative and significant $(-0.103 * * *)$. Of the three controls considered, only the coefficient of $\mathrm{BN}_{\mathrm{it}} \mathrm{R}_{\mathrm{it}} \mathrm{SIZE}_{\mathrm{it}}$ is significant and negative, i.e. larger firms have lower asymmetric timeliness of earnings. This is consistent with previous studies (Easley et al.,

\footnotetext{
13 The low number of observations in Italy for the pre-IFRS period is explained by the fact that the beta coefficient is not available in Datastream for the years before 2004.

${ }^{14}$ Following (Barth et al., 2008; Barth et al., 2011) who argue that in international samples outliers might bias the results more heavily we winsorize at $5 \%$ level.

${ }^{15}$ For a review of value relevance studies conducted in Europe, see Dumontier and Raffournier (2002).
} 
2002; Khan and Watts, 2009), larger firms are more mature and have richer information environments and therefore lower information asymmetry, which in turn suggests a lower demand for conditional conservatism. The third column in Table 2 reports the results of the regression from model (3) that takes into account the influence of the cost of capital and unconditional conservatism. The change to IFRS $\left(B N_{i t} R_{i t} I F R S_{i t}\right)$ remains significant and negative $(-0.128 * * *)$ again denoting a significant reduction in conditional conservatism.

Finally, the last column in Table 2 represents the expanded version of the Basu (1997) model and includes all control variables that might impact the demand for conservatism. The impact of IFRS on conditional conservatism $\left(B \mathrm{BN}_{\mathrm{it}} \mathrm{R}_{\mathrm{it}} I F R S_{\mathrm{it}}\right)$ remains significant and negative $\left(-0.091^{* * *}\right)$, while the timely gain recognition as captured by the coefficient $\mathrm{R}_{\mathrm{it}} I F R S_{\mathrm{it}}$ is positive and significant $\left(0.026^{* *}\right)$. From the control variables only the size and the cost of capital seem to negatively influence the level of conditional conservatism. As predicted, the coefficient $\mathrm{BN}_{\mathrm{it}} \mathrm{R}_{\mathrm{it}} \mathrm{SIZE}_{\mathrm{it}}$ is negative and significant (-0.028***) confirming an inverse relationship between the size of the firm and the level of conditional conservatism. The coefficient on $B N_{i t} R_{i t} B E T A_{i t}$ is positive and slightly significant denoting a direct relationship between the level of conditional conservatism and the cost of capital. Our proxy for unconditional conservatism (i.e. $\mathrm{UCC}_{\mathrm{it}}$ ) although exhibiting the expected negative sign does not seem to statistically influence conditional conservatism.

\section{(ii) The role of institutional factors on the change in the degree of conditional conservatism}

Table 3 captures the relative importance of enforcement and corporate governance mechanisms in shaping the level of conditional conservatism. As expected, in most of the cases the level of conditional conservatism is higher for high enforcement/corporate governance quality settings (both for the pre- and post-IFRS, the differences are positive and significant for ENF, $0.164 * * *$ pre and $0.106^{* *}$ post, and for GOV7, 0.104** pre and $0.075^{*}$ post). For all the proxies considered, the mandatory IFRS adoption has significantly decreased the level of conditional conservatism only in high enforcement / corporate governance quality environments (the difference is $-0.090 * *$ and $-0.088 * *$ for ENF and GOV7, respectively), while this difference is never significant for low enforcement / corporate governance quality settings. These results corroborate the findings of Ahmed et al. (2013) who also report a more significant decrease in the timeliness of loss recognition for high enforcement countries. The authors suggest that enforcement mechanisms in these countries were not able to counter the initial effects of greater flexibility in IFRS relative to domestic GAAP. 


\section{INSERT TABLE 3 ABOUT HERE}

Table 4 combines the effects of legal, governance, enforcement and market type characteristics. We find that asymmetric loss recognition has significantly decreased for countries with outsider economies and well-developed stock markets, dispersed ownership, and strong investor protection (i.e. cluster 1: Great Britain and Norway) and for countries with more insider type economies and less developed stock markets, concentrated ownership, weak investor rights, but strong enforcement (i.e. cluster 2: Austria, Belgium, Denmark, Finland, France, Germany, Ireland, Netherlands, Sweden, and Switzerland). For the cluster 3, the level of conditional conservatism does not change significantly. Consistent with prior literature Bushman and Piotroski (2006) and Bona-Sánchez et al. (2011), insider dominated economies combined with weak enforcement (i.e., cluster 3: Greece, Italy, Portugal, and Spain) exhibit lower levels of conservatism before IFRS $(-0.257 * * *)$, while this difference becomes not significant after the adoption of IFRS (-0.042).

\section{INSERT TABLE 4 ABOUT HERE}

\section{(iii) The role of impairment tests}

The previously reported results suggest that legal, governance, enforcement and market type characteristics were not able to counter the initial effects of greater flexibility in IFRS relative to domestic GAAP (Ahmed et al., 2013). The effect of the adoption of IFRS in 2005 on conditional conservatism in Europe is therefore most likely dependent on the capacity to apply various conditional conservatism mechanisms, among which impairment testing for non-financial assets plays a central role in IFRS. Therefore, Table 5 splits the sample between firm-year observations where inappropriate enforcement of impairment testing mechanisms is more probable. The conjecture is that firms with intangibles and in particular goodwill are more probably to be affected by the mandatory adoption of IFRS due to the new impairment testing mechanisms. The decrease in conditional conservatism is significant only for the firms that report intangibles and goodwill in their balance sheets (the difference is $-0.104 * * *$ and $0.106^{* * *}$, respectively). 
Finally, we focus on the observations that report intangibles and goodwill in their balance sheet and that have impaired these assets during the current year. If those impairments were untimely (delayed), we should observe a larger drop in the level of conditional conservatism for those observations. Indeed, earnings are reduced when there is no bad news whereas when there is a bad news, the impairment is not booked and there is no earnings reduction. The change following the mandatory IFRS adoption is negative and more important for firms that have impaired intangibles $(-0.240 * * *)$ and goodwill $(-0.291 * * *)$. These findings support our conjecture that impairment tests for intangible assets and goodwill are the most sensitive to management assumptions and are potentially manipulated. This result indicates that impairment principles are inappropriately applied by firms and enforced by European regulators, in particular in traditionally 'strong enforcement' countries. We therefore identify one important accounting mechanism that is associated with the decrease in the degree of conditional conservatism.

\section{INSERT TABLE 5 ABOUT HERE}

\section{CONCLUSION}

The adoption of IFRS in Europe was to achieve better quality financial reporting. Since then, numerous studies have looked at different pieces of the puzzle. We examine conditional conservatism and document a decrease after the adoption even though IFRS have reduced the level of unconditional conservatism and put in place mechanisms to ensure conditional conservatism such as impairment testing. In order to better understand this result, we examine if market and institutional factors such as enforcement, governance, investor protection and market type are associated with this decrease. We document that the decrease has occurred in strong enforcement/governance countries, with no change in the converse. In further investigating, we show that the decrease is greatest in firms having high levels of intangibles. We conclude that inappropriate impairment testing is a potential explanation. Our results inform standard-setting stakeholders about a potential negative effect of the greater flexibility permitted by IFRS on a key dimension of accounting quality. They are important for European regulators and standard setters as they review the cost and benefits of IFRS.

As indicated earlier, the implementation of impairment tests (in particular for intangibles with indefinite useful life) usually relies on valuation models, requires 'significant judgment' from managers, and is prone to manipulation by managers because it relies on 
unverifiable fair value estimates. The European Securities and Market Authority (ESMA) recently expressed concerns about insufficient impairment recognition by major listed European companies during the financial crisis (see ESMA, 2013). Various professional reports by large auditors or other consulting firms have also documented this lack of recognition of economic impairment for several years. Further studies have documented an incomplete and heterogeneous level of compliance with disclosure requirements under IFRS 3 and IAS 36 (Amiraslani et al. 2013; Mazzi et al. 2013; Tsalavoutas et al. forthcoming). Finally, the press recently echoed insufficient and untimely recognition of economic impairment for goodwill. The effect of the adoption of IFRS in 2005 on conditional conservatism in Europe is most likely dependent on the capacity to apply and enforce various conditional conservatism mechanisms, among which impairment testing principles for nonfinancial assets play a critical role. 


\section{References}

Amiraslani, H., G. E. Iatridis and P. F. Pope (2013) Accounting for asset impairment: A test for IFRS compliance across Europe, A research report by the centre for Financial Aanalysis and Reporting Research, Cass Business School, 2013, 68p.

Aggarwal, R., I. Erel, R. M. Stulz, and R. Williamson (2009), 'Differences in Governance Practices between U.S. and Foreign Firms: Measurement, Causes, and Consequences', Review of Financial Studies, Vol. 22, pp. 3131-3169.

Ahmed, A. S., M. Neel, and D. Wang (2013), 'Does mandatory adoption of IFRS improve accounting quality? Preliminary evidence', Contemporary Accounting Research, Vol. Forthcoming.

Ball, R., S. P. Kothari, and V. V. Nikolaev (2013), 'On estimating conditional conservatism', Accounting Review, Vol. 88, pp. 755-787.

Ball, R., S. P. Kothari, and A. Robin (2000), 'The effect of international institutional factors on properties of accounting earnings', Journal of Accounting \& Economics, Vol. 29, pp. 1-51.

Ball, R., A. Robin, and G. Sadka (2008), 'Is financial reporting shaped by equity markets or by debt markets? An international study of timeliness and conservatism', Review of Accounting Studies, Vol. 13, pp. 168-205.

Ball, R., A. Robin, and J. S. Wu (2003), 'Incentives versus standards: Properties of accounting income in four east asian countries', Journal of Accounting \& Economics, Vol. 36, pp. 235.

Ball, R., and L. Shivakumar (2005), 'Earnings quality in uk private firms: Comparative loss recognition timeliness', Journal of Accounting \& Economics, Vol. 39, pp. 83-128.

Barth, M. E., W. R. Landsman, and M. H. Lang (2008), 'International accounting standards and accounting quality', Journal of Accounting Research, Vol. 46, pp. 467-498.

Barth, M. E., W. R. Landsman, M. H. Lang, and C. Williams (2011), 'Are international accounting standards-based and us gaap-based accounting amounts comparable?', Working paper available on ssrn, Vol.

Basu, S. (1997), 'The conservatism principle and the asymmetric timeliness of earnings', Journal of Accounting \& Economics, Vol. 24, pp. 3-37.

Beaver, W. H., and S. G. Ryan (2005), 'Conditional and unconditional conservatism:Concepts and modeling', Review of Accounting Studies, Vol. 10, pp. 269-309.

Bens, D. A., W. Heltzer, and B. Segal (2011), 'The information content of goodwill impairments and SFAS 142', Journal of Accounting, Auditing \& Finance, Vol. 26, pp. 527-555.

Bona-Sánchez, C., J. Pérez-Alemán, and D. J. Santana-Martín (2011), 'Ultimate ownership and earnings conservatism', European Accounting Review, Vol. 20, pp. 57-80.

Brüggemann, U., J.-M. Hitz, and T. Sellhorn (2013), 'Intended and unintended consequences of mandatory IFRS adoption: A review of extant evidence and suggestions for future research', European Accounting Review, Vol. 22, pp. 1-37.

Burgstahler, D., L. Hail, and C. Leuz (2006), 'The importance of reporting incentives: Earnings management in eouropean private and public firms', The Accounting Review, Vol. 81, pp. 983-1016. 
Bushman, R. M., and J. D. Piotroski (2006), 'Financial reporting incentives for conservative accounting: The influence of legal and political institutions', Journal of Accounting \& Economics, Vol. 42, pp. 107-148.

Bushman, R. M., J. D. Piotroski, and A. J. Smith (2011), 'Capital allocation and timely accounting recognition of economic losses', Journal of Business Finance \& Accounting, Vol. 38, pp. 1-33.

Capkun, V., A. Cazavan-Jeny, T. Jeanjean, and L. A. Weiss (2008), 'Earnings management and value relevance during mandatory transition from local gaaps to IFRS in Europe', Working paper, Vol.

Christensen, H. B., E. Lee, and M. Walker (2008), 'Incentives or standards: What determines accounting quality changes around IFRS adoption?', Working paper, Vol. Manchester Business School.

Daske, H., L. Hail, C. Leuz, and R. Verdi (2008), 'Mandatory IFRS reporting around the world: Early evidence on the economic consequences', Journal of Accounting Research, Vol. 46, pp. 1085-1142.

--- (2013), 'Adopting a label: Heterogeneity in the economic consequences around IAS/IFRS adoptions', Journal of Accounting Research, Vol. 51, pp. 495-547.

Dechow, P., W. Ge, and C. Schrand (2010), 'Understanding earnings quality: A review of the proxies, their determinants and their consequences', Journal of Accounting \& Economics, Vol. 50, pp. 344-401.

DeFond, M., M. Hung, and R. Trezevant (2007), 'Investor protection and the information content of annual earnings announcements: International evidence', Journal of Accounting \& Economics, Vol. 43, pp. 37-67.

Dickhaut, J., S. Basu, K. McCabe, and G. Waymire (2010), 'Neuroaccounting: Consilience between the biologically evolved brain and culturally evolved accounting principles', Accounting Horizons, Vol. 24, pp. 221-225.

Dumontier, P., and B. Raffournier (2002), 'Accounting and capital markets: A survey of the European evidence', European Accounting Review, Vol. 11, pp. 119-151.

Durnev, A. R. T., and E. H. Kim (2005), 'To steal or not to steal: Firm attributes, legal environment, and valuation', Journal of Finance, Vol. 60, pp. 1461-1493.

Easley, D., S. Hvidkjaer, and M. O'Hara (2002), 'Is information risk a determinant of asset returns?', Journal of Finance, Vol. 57, pp. 2185-2221.

EFRAG, ANC, ASCG, OIC, and FRC (2013), 'Getting a better framework - prudence bulletin', Vol.

Ernst_\&_Young (2010), 'Meeting today's financial challenges - impairment reporting: Improving stakeholder confidence', Ernst \& Young, Vol.

ESMA (2013), 'European enforcers review of impairment of goodwill and other intangible assets in the IFRS financial statements', European Securities and Markets Authority, Vol.

Filip, A. (2010), ' IFRS and the value relevance of earnings: Evidence from the emerging market of romania', International Journal of Accounting, Auditing and Performance Evaluation, Vol. 6, pp. 191-223. 
Filip, A., and B. Raffournier (2011), 'The value relevance of accounting figures in Europe after IFRS implementation: The relative influence of legal incentives, market forces and firm characteristics', Working paper, Vol.

Francis, J., R. LaFond, P. M. Olsson, and K. Schipper (2004), 'Costs of equity and earnings attributes', Accounting Review, Vol. 79, pp. 967-1010.

Francis, J., P. Olsson, and K. Schipper (2006), 'Earnings quality', Foundations \& Trends in Accounting, Vol. 1, pp. 259-260.

Gaio, C. (2010), 'The relative importance of firm and country characteristics for earnings quality around the world', European Accounting Review, Vol. 19, pp. 693-738.

García Lara, J. M., and A. Mora (2004), 'Balance sheet versus earnings conservatism in Europe', European Accounting Review, Vol. 13, pp. 261-292.

Gassen, J., R. U. Fülbier, and T. Sellhorn (2006), 'International differences in conditional conservatism - the role of unconditional conservatism and income smoothing', European Accounting Review, Vol. 15, pp. 527-564.

Giner, B., and W. Rees (2001), 'On the asymmetric recognition of good and bad news in france, germany and the united kingdom', Journal of Business Finance \& Accounting, Vol. 28, pp. 1285.

Hayn, C., and P. J. Hughes (2006), 'Leading indicators of goodwill impairment', Journal of Accounting, Auditing \& Finance, Vol. 21, pp. 223-265.

Holthausen, R. W. (2009), 'Accounting standards, financial reporting outcomes, and enforcement', Journal of Accounting Research, Vol. 47, pp. 447-458.

Hope, O.-K. (2003), 'Disclosure practices, enforcement of accounting standards, and analysts' forecast accuracy: An international study', Journal of Accounting Research, Vol. 41, pp. 235-272.

Houlihan_Lokey (2013), 'The European goodwill impairment study 2012-2013', Vol.

IASB. (2004), 'International accounting standard (IAS) No. 36: Impairment of assets'. London: IASC Foundation Publications Department.

--- (2008), 'Exposure draft: An improved conceptual framework for financial reporting: Chapters 1 and 2', IFRS Foundation, Vol.

---. (2010), 'Conceptual framework for financial reporting (the IFRS framework)'. London.: IFRS Foundation.

IDW (2005), 'Institut der wirstschaftprüfer standard: Principles for the performance of business valuations', IDW Verlag Gmbh, Vol.

--- (2008), 'Institut der wirstschaftprüfer standard: Principles for the performance of business valuations', IDW Verlag Gmbh, Vol.

Karamanou, I., and G. P. Nishiotis (2009), 'Disclosure and the cost of capital: Evidence from the market's reaction to firm voluntary adoption of IAS', Journal of Business Finance \& Accounting, Vol. 36, pp. 793-821.

Khan, M., and R. L. Watts (2009), 'Estimation and empirical properties of a firm-year measure of accounting conservatism', Journal of Accounting \& Economics, Vol. 48, pp. 132-150. 
Kim, S., C. Lee, and S. W. Yoon (2013), 'Goodwill accounting and asymmetric timeliness of earnings', Review of Accounting and Finance, Vol. Forthcoming.

Kothari, S. P., K. Ramanna, and D. J. Skinner (2010), 'Implications for gaap from an analysis of positive research in accounting', Journal of Accounting \& Economics, Vol. 50, pp. 246-286.

La Porta, R., F. Lopez-de-Silanes, A. Shleifer, and R. W. Vishny (1997), 'Legal determinants of external financing', The Journal of Finance, Vol. 52, pp. 1131-1150.

--- (1998), 'Law and finance', Journal of Political Economy, Vol. 106, pp. 1113.

Leuz, C., D. Nanda, and P. D. Wysocki (2003), 'Earnings management and investor protection: An international comparison', Journal of Financial Economics, Vol. 69, pp. 505-527.

Li, K. K., and R. G. Sloan (2011), 'Has goodwill accounting gone bad?', Canadian Academic Accounting Association, Annual Conference, Toronto, Vol.

Li, S. (2010), 'Does mandatory adoption of international financial reporting standards in the European union reduce the cost of equity capital?', Accounting Review, Vol. 85, pp. 607-636.

Littleton, A. C. (1941), 'A genealogy for "cost or market"', The Accounting Review, Vol. 16, pp. 161-167.

Mazzi, F., P. André, D. Dyonisia and I. Tsalavoutas (2013) Goodwill related mandatory disclosure and the cost of equity capital, Working paper ESSEC KPMG Financial Reporting Centre, 51p.

Nobes, C., and R. Parker. (2010), 'Comparative international accounting'. FT Prentice Hall, 11 th ed.

Patatoukas, P. N., and J. K. Thomas (2011), 'More evidence of bias in the differential timeliness measure of conditional conservatism', Accounting Review, Vol. 86, pp. 1765-1793.

Petersen, C., and T. Plenborg (2010), 'How do firms implement impairment tests of goodwill?', Abacus, Vol. 46, pp. 419-446.

Piot, C., P. Dumontier, and R. Janin (2010), 'IFRS consequences on accounting conservatism within Europe', Working paper, Vol.

Piot, C., P. Dumontier, and R. Janin (2011), 'IFRS consequences on accounting conservatism within Europe: The role of big 4 auditors', Working paper, Vol. Université de Grenoble.

Pope, P. F., and M. Walker (1999), 'International differences in the timeliness, conservatism, and classification of earnings', Journal of Accounting Research, Vol. 37, pp. 53-87.

--- (2003), 'Ex-ante and ex-post accounting conservatism, asset recognition and asymmetric earnings timeliness', Working paper, Vol. Lancaster University and University of Manchester.

Ramanna, K. (2008), 'The implications of unverifiable fair-value accounting: Evidence from the political economy of goodwill accounting', Journal of Accounting \& Economics, Vol. 45, pp. 253-281.

Ramanna, K., and R. Watts (2012), 'Evidence on the use of unverifiable estimates in required goodwill impairment', Review of Accounting Studies, Vol. 17, pp. 749-780. 
Raonic, I., S. McLeay, and I. Asimakopoulos (2004), 'The timeliness of income recognition by European companies: An analysis of institutional and market complexity', Journal of Business Finance \& Accounting, Vol. 31, pp. 115-148.

Renders, A., and A. Gaeremynck (2007), 'The impact of legal and voluntary investor protection on the early adoption of international financial reporting standards (IFRS)', De Economist (0013-063X), Vol. 155, pp. 49-72.

Roychowdhury, S., and R. L. Watts (2007), 'Asymmetric timeliness of earnings, market-tobook and conservatism in financial reporting', Journal of Accounting \& Economics, Vol. 44, pp. 2-31.

Ryan, S. G. (2006), 'Identifying conditional conservatism', European Accounting Review, Vol. 15 , pp. 511-525.

Tsalavoutas, I. P. André, and D. Dyonisia, forthcoming, Worldwide IFRS adoption and convergence: mandated disclosures and the financial statement effects of IFRS 3, IAS 36 and IAS 38, A research report by ACCA,

Tsalavoutas, I., P. André, and L. Evans (2012), 'The transition to IFRS and the value relevance of financial statements in greece', British Accounting Review, Vol. 44, pp. 262-277.

Walton, P. (2011), 'An executive guide to IFRS: Content, costs and benefits to business'.

Watts, R. L. (2003a), 'Conservatism in accounting part i: Explanations and implications', Accounting Horizons, Vol. 17, pp. 207-221.

--- (2003b), 'Conservatism in accounting part ii: Evidence and research opportunities', Accounting Horizons, Vol. 17, pp. 287-301. 
Panel A: Sampling

\begin{tabular}{|c|c|}
\hline Firms from 16 countries & 8,379 \\
\hline ( - ) Financial institutions & 2,554 \\
\hline ( - ) Non 2005 IFRS adopters & 3,029 \\
\hline ( = ) Firms included in the sample & 2,796 \\
\hline ( x6 ) Firm-years observations for 2002 to 2007 & 16,776 \\
\hline ( - ) Observations with unavailable data & 9,293 \\
\hline ( - ) Observations with negative equity or negative total assets & 232 \\
\hline ( - ) Final number of firm-years observations & 7,251 \\
\hline
\end{tabular}

Panel B: Distribution of the sample by country

\begin{tabular}{lrrr}
\hline Country & Before & After & Pool \\
\hline Austria & 38 & 36 & 74 \\
Belgium & 74 & 80 & 154 \\
Denmark & 105 & 97 & 202 \\
Finland & 148 & 158 & 306 \\
France & 579 & 684 & 1,263 \\
Germany & 416 & 477 & 893 \\
Great Britain & 665 & 567 & 1,232 \\
Greece & 133 & 375 & 508 \\
Ireland & 45 & 49 & 94 \\
Italy & 86 & 321 & 407 \\
Netherlands & 165 & 182 & 347 \\
Norway & 142 & 183 & 325 \\
Portugal & 54 & 53 & 107 \\
Spain & 165 & 173 & 338 \\
Sweden & 353 & 435 & 788 \\
Switzerland & 107 & 106 & 213 \\
\hline
\end{tabular}




\begin{tabular}{lrrrrr}
\hline Variable & Mean & Median & Std. dev. & Min & Max \\
\hline $\mathrm{R}_{\text {it }}$ & 0.207 & 0.143 & 0.435 & -0.472 & 1.251 \\
$\mathrm{NI}_{\text {it }}$ & 0.037 & 0.060 & 0.114 & -0.287 & 0.205 \\
SIZE $_{\text {it }}$ & 5.529 & 5.394 & 2.005 & 2.291 & 9.488 \\
MB $_{\text {it }}$ & 2.330 & 1.843 & 1.670 & 0.557 & 6.962 \\
LEV $_{\text {it }}$ & 0.564 & 0.302 & 0.697 & 0.000 & 2.627 \\
BETA $_{\text {it }}$ & 0.779 & 0.660 & 0.599 & -0.017 & 2.071 \\
UCC $_{\text {it }}$ & -0.027 & -0.232 & 1.159 & -1.681 & 2.877 \\
INTAN $_{\text {it }}$ & 0.144 & 0.081 & 0.159 & 0.000 & 0.528 \\
PPEN $_{\text {it }}$ & 0.263 & 0.219 & 0.209 & 0.012 & 0.714 \\
CAPEX $_{\text {it }}$ & 0.043 & 0.033 & 0.036 & 0.002 & 0.136 \\
$\Delta$ SALES $_{\text {it }}$ & 0.087 & 0.059 & 0.207 & -0.277 & 0.626 \\
ROE $_{\text {it }}$ & 0.057 & 0.099 & 0.208 & -0.582 & 0.333 \\
VOLAT $_{i t}$ & 31.804 & 29.251 & 11.870 & 15.263 & 56.279 \\
DINT $_{\text {it }}$ & 0.927 & 1.000 & 0.260 & 0.000 & 1.000 \\
DGW $_{\text {it }}$ & 0.726 & 1.000 & 0.446 & 0.000 & 1.000 \\
DIMPINT $_{\text {it }}$ & 0.135 & 0.000 & 0.342 & 0.000 & 1.000 \\
DIMPGW $_{\text {it }}$ & 0.105 & 0.000 & 0.306 & 0.000 & 1.000 \\
\hline
\end{tabular}

Where:

$\mathrm{R}_{\mathrm{it}} \quad$ market return of firm $\mathrm{i}$ in year $\mathrm{t}$, net of dividends and capital contributions;

$\mathrm{NI}_{\mathrm{it}} \quad$ net income of firm $\mathrm{i}$ in year $\mathrm{t}$, scaled by beginning of the period market value;

SIZE $_{i t} \quad \log$ of the market value of firm $i$ at the end of the year $t$;

$\mathrm{MB}_{\text {it }} \quad$ market-to-book ratio of firm $\mathrm{i}$ at the end of the year $\mathrm{t}$;

$\mathrm{LEV}_{\mathrm{it}} \quad$ leverage of firm $\mathrm{i}$ at the end of the year $\mathrm{t}$, defined as total debt scaled by market value;

BETA $_{\text {it }} \quad$ beta coefficient of firm $i$ in year $t$;

$\mathrm{UCC}_{\mathrm{it}} \quad$ measure of unconditional conservatism of firm $\mathrm{i}$ in year $\mathrm{t}$;

INTAN $_{\text {it }} \quad$ intangible assets of firm $i$ at the end of the year $t$, scaled by total assets;

PPEN $_{\mathrm{it}} \quad$ net value of property plant and equipment of firm $i$ at the end of the year $t$, scaled by total assets;

CAPEX $_{\text {it }} \quad$ capital expenditures of firm $i$ in year $t$, scaled by total assets;

$\triangle$ SALES $_{\text {it }} \quad$ percentage change in sales of firm i in year $t$;

ROE $_{\text {it }} \quad$ net income of firm $\mathrm{i}$ in year $\mathrm{t}$, scaled by equity;

VOLATit price volatility of the share of the firm $i$ in year $t$;

DINTit is a dummy variable equal to 1 if INTAN it $_{\text {it }}$ positive, and 0 otherwise;

DGW $_{\text {it }} \quad$ is a dummy variable equal to 1 if the goodwill of firm $i$ at the end of the year $t$ is positive, and 0

otherwise;

DIMPINTit is a dummy variable equal to 1 if DINTAN $_{\mathrm{it}}$ is 1 and the intangibles have been impaired during the year $\mathrm{t}$, and 0 otherwise;

DIMPGW $_{\text {it }}$ is a dummy variable equal to 1 if the goodwill of firm $i$ at the end of the year $t$ is positive and the goodwill has been impaired during the year $\mathrm{t}$, and 0 otherwise.

All continuous variables are winsorized at $5 \%$. 
Table 2. The impact of IFRS on conditional conservatism

\begin{tabular}{|c|c|c|c|c|c|c|c|c|}
\hline \multirow[b]{2}{*}{ Intercept } & \multicolumn{2}{|c|}{ Model 1} & \multicolumn{2}{|c|}{ Model 2} & \multicolumn{2}{|c|}{ Model 3} & \multicolumn{2}{|c|}{ Model 4} \\
\hline & $\begin{array}{r}0.055 \\
(14.26)\end{array}$ & $* * *$ & $\begin{array}{l}0.027 \\
(2.97)\end{array}$ & $* * *$ & $\begin{array}{r}0.060 \\
(13.72)\end{array}$ & $* * *$ & $\begin{array}{r}0.030 \\
(3.19)\end{array}$ & $* * *$ \\
\hline $\mathrm{BN}_{\mathrm{it}}$ & $\begin{array}{l}-0.018 \\
(-2.57)\end{array}$ & ** & $\begin{array}{l}-0.016 \\
(-0.98)\end{array}$ & & $\begin{array}{l}-0.015 \\
(-1.75)\end{array}$ & $*$ & $\begin{array}{l}0.000 \\
(0.01)\end{array}$ & \\
\hline $\mathrm{R}_{\mathrm{it}}$ & $\begin{array}{l}0.005 \\
(0.55)\end{array}$ & & $\begin{array}{l}0.027 \\
(1.29)\end{array}$ & & $\begin{array}{l}0.039 \\
(3.98)\end{array}$ & $* * *$ & $\begin{array}{l}0.082 \\
(3.60)\end{array}$ & $* * *$ \\
\hline $\mathrm{BN}_{\mathrm{it}} \mathrm{R}_{\mathrm{it}}$ & $\begin{array}{r}0.278 \\
(11.11)\end{array}$ & $* * *$ & $\begin{array}{l}0.341 \\
(5.65)\end{array}$ & $* * *$ & $\begin{array}{l}0.242 \\
(6.78)\end{array}$ & $* * *$ & $\begin{array}{l}0.250 \\
(3.51)\end{array}$ & $* * *$ \\
\hline IFRS $_{\text {it }}$ & $\begin{array}{l}-0.001 \\
(-0.24)\end{array}$ & & $\begin{array}{l}0.001 \\
(0.14)\end{array}$ & & $\begin{array}{l}0.004 \\
(0.83)\end{array}$ & & $\begin{array}{l}0.005 \\
(1.11)\end{array}$ & \\
\hline $\mathrm{BN}_{\mathrm{it}} \mathrm{IFRS}_{\mathrm{it}}$ & $\begin{array}{l}0.002 \\
(0.24)\end{array}$ & & $\begin{array}{l}0.002 \\
(0.18)\end{array}$ & & $\begin{array}{l}-0.002 \\
(-0.20)\end{array}$ & & $\begin{array}{l}0.002 \\
(0.23)\end{array}$ & \\
\hline $\mathrm{R}_{\mathrm{it}} \mathrm{IFRS} S_{\mathrm{it}}$ & $\begin{array}{l}0.030 \\
(2.82)\end{array}$ & $* * *$ & $\begin{array}{l}0.029 \\
(2.72)\end{array}$ & $* * *$ & $\begin{array}{l}0.024 \\
(2.32)\end{array}$ & $* *$ & $\begin{array}{l}0.026 \\
(2.46)\end{array}$ & $* *$ \\
\hline $\mathrm{BN}_{\mathrm{it}} \mathrm{R}_{\mathrm{it}} \mathrm{IFRS}_{\mathrm{it}}$ & $\begin{array}{l}-0.135 \\
(-4.17)\end{array}$ & $* * *$ & $\begin{array}{l}-0.103 \\
(-3.28)\end{array}$ & $* * *$ & $\begin{array}{l}-0.128 \\
(-3.99)\end{array}$ & $* * *$ & $\begin{array}{l}-0.091 \\
(-2.90)\end{array}$ & $* * *$ \\
\hline $\mathrm{SIZE}_{\mathrm{it}}$ & & & $\begin{array}{l}0.009 \\
(7.25)\end{array}$ & $* * *$ & & & $\begin{array}{l}0.010 \\
(7.23)\end{array}$ & $* * *$ \\
\hline $\mathrm{BN}_{\mathrm{it}} \mathrm{SIZE}_{\mathrm{it}}$ & & & $\begin{array}{l}0.004 \\
(1.74)\end{array}$ & $*$ & & & $\begin{array}{l}0.005 \\
(2.04)\end{array}$ & $* *$ \\
\hline $\mathrm{R}_{\mathrm{it}} \mathrm{SIZE}_{\mathrm{it}}$ & & & $\begin{array}{l}0.001 \\
(0.37)\end{array}$ & & & & $\begin{array}{l}0.003 \\
(0.90)\end{array}$ & \\
\hline $\mathrm{BN}_{\mathrm{it}} \mathrm{R}_{\mathrm{it}} \mathrm{SIZE}_{\mathrm{it}}$ & & & $\begin{array}{l}-0.022 \\
(-2.43)\end{array}$ & $* *$ & & & $\begin{array}{l}-0.028 \\
(-3.06)\end{array}$ & $* * *$ \\
\hline $\mathrm{MB}_{\mathrm{it}}$ & & & $\begin{array}{l}-0.012 \\
(-7.63)\end{array}$ & $* * *$ & & & $\begin{array}{l}-0.013 \\
(-4.18)\end{array}$ & $* * *$ \\
\hline $\mathrm{BN}_{\mathrm{it}} \mathrm{MB}_{\mathrm{it}}$ & & & $\begin{array}{l}-0.002 \\
(-0.89)\end{array}$ & & & & $\begin{array}{l}-0.011 \\
(-1.67)\end{array}$ & * \\
\hline $\mathrm{R}_{\mathrm{it}} \mathrm{MB}_{\mathrm{it}}$ & & & $\begin{array}{l}-0.004 \\
(-1.29)\end{array}$ & & & & $\begin{array}{l}-0.014 \\
(-2.11)\end{array}$ & $* *$ \\
\hline $\mathrm{BN}_{\mathrm{it}} \mathrm{R}_{\mathrm{it}} \mathrm{MB}_{\mathrm{it}}$ & & & $\begin{array}{l}-0.011 \\
(-0.97)\end{array}$ & & & & $\begin{array}{l}0.009 \\
(0.41)\end{array}$ & \\
\hline $\mathrm{LEV}_{\text {it }}$ & & & $\begin{array}{l}-0.005 \\
(-0.87)\end{array}$ & & & & $\begin{array}{l}-0.005 \\
(-0.95)\end{array}$ & \\
\hline $\mathrm{BN}_{\mathrm{it}} \mathrm{LEV}_{\mathrm{it}}$ & & & $\begin{array}{l}-0.026 \\
(-3.14)\end{array}$ & $* * *$ & & & $\begin{array}{l}-0.033 \\
(-3.60)\end{array}$ & $* * *$ \\
\hline $\mathrm{R}_{\mathrm{it}} \mathrm{LEV}_{\mathrm{it}}$ & & & $\begin{array}{l}-0.009 \\
(-0.79)\end{array}$ & & & & $\begin{array}{l}-0.020 \\
(-1.73)\end{array}$ & $*$ \\
\hline $\mathrm{BN}_{\mathrm{it}} \mathrm{R}_{\mathrm{it}} \mathrm{LEV}_{\mathrm{it}}$ & & & $\begin{array}{l}-0.011 \\
(-0.42)\end{array}$ & & & & $\begin{array}{l}0.008 \\
(0.28)\end{array}$ & \\
\hline
\end{tabular}




\begin{tabular}{|c|c|c|c|c|c|c|}
\hline BETA $_{\text {it }}$ & & & $\begin{array}{l}-0.015 \\
(-3.82)\end{array}$ & $* * *$ & $\begin{array}{l}-0.012 \\
(-3.08)\end{array}$ & $* * *$ \\
\hline $\mathrm{BN}_{\mathrm{it}} \mathrm{BETA}_{\mathrm{it}}$ & & & $\begin{array}{r}0.005 \\
(0.64)\end{array}$ & & $\begin{array}{c}0.005 \\
(0.78)\end{array}$ & \\
\hline $\mathrm{R}_{\mathrm{it}} \mathrm{BETA}_{\mathrm{it}}$ & & & $\begin{array}{l}-0.028 \\
(-3.49)\end{array}$ & $* * *$ & $\begin{array}{l}-0.027 \\
(-3.24)\end{array}$ & $* * *$ \\
\hline $\mathrm{BN}_{\mathrm{it}} \mathrm{R}_{\mathrm{it}} \mathrm{BETA}_{\mathrm{it}}$ & & & $\begin{array}{c}0.027 \\
(0.93)\end{array}$ & & $\begin{array}{c}0.053 \\
(1.83)\end{array}$ & * \\
\hline $\mathrm{UCC}_{\mathrm{it}}$ & & & $\begin{array}{l}-0.011 \\
(-5.27)\end{array}$ & $* * *$ & $\begin{array}{c}0.002 \\
(0.39)\end{array}$ & \\
\hline $\mathrm{BN}_{\mathrm{it}} \mathrm{UCC}_{\mathrm{it}}$ & & & $\begin{array}{c}0.003 \\
(0.64)\end{array}$ & & $\begin{array}{c}0.013 \\
(1.48)\end{array}$ & \\
\hline $\mathrm{R}_{\mathrm{it}} \mathrm{UCC}_{\mathrm{it}}$ & & & $\begin{array}{c}-0.001 \\
(-0.18)\end{array}$ & & $\begin{array}{c}0.016 \\
(1.91)\end{array}$ & $*$ \\
\hline $\mathrm{BN}_{\mathrm{it}} \mathrm{R}_{\mathrm{it}} \mathrm{UCC}_{\mathrm{it}}$ & & & $\begin{array}{r}0.008 \\
(0.51) \\
\end{array}$ & & $\begin{array}{r}-0.034 \\
(-1.10) \\
\end{array}$ & \\
\hline $\mathrm{N}$ & 7251 & 7251 & 7251 & & 7251 & \\
\hline Adj. $R^{2}$ & 0.157 & 0.235 & 0.186 & & 0.255 & \\
\hline
\end{tabular}

Sample consists of European mandatory adopters of IFRS in 2005 from 16 countries (Austria, Belgium, Denmark, Finland, France, Germany, Great Britain, Greece, Ireland, Italy, Netherlands, Norway, Portugal, Spain, Sweden, and Switzerland). Sample period spans 2002-2007.

Expanded model: $\mathrm{NI}_{\mathrm{it}}=\alpha_{1}+\alpha_{2} \mathrm{BN}_{\mathrm{it}}+\alpha_{3} \mathrm{R}_{\mathrm{it}}+\alpha_{4} \mathrm{BN}_{\mathrm{it}} \mathrm{XR}_{\mathrm{it}}+$

$+\alpha_{5} \mathrm{IFRS}_{\mathrm{it}}+\alpha_{6} \mathrm{BN}_{\mathrm{it}} \mathrm{IFRS} \mathrm{Sit}_{\mathrm{it}}+\alpha_{7} \mathrm{R}_{\mathrm{it}} \mathrm{IFRS}_{\mathrm{it}}+\alpha_{8} \mathrm{BN}_{\mathrm{it}} \mathrm{R}_{\mathrm{it}} \mathrm{IFRS}_{\mathrm{it}}+$

$+\alpha_{9} \mathrm{SIZE}_{\mathrm{it}}+\alpha_{10} \mathrm{BN}_{\mathrm{it}} \mathrm{SIZE}_{\mathrm{it}}+\alpha_{11} \mathrm{R}_{\mathrm{it}} \mathrm{SIZE}_{\mathrm{it}}+\alpha_{12} \mathrm{BN}_{\mathrm{it}} \mathrm{R}_{\mathrm{it}} \mathrm{SIZE}_{\mathrm{it}}+$

$+\alpha_{13} \mathrm{MB}_{\mathrm{it}}+\alpha_{14} \mathrm{BN}_{\mathrm{it}} \mathrm{MB}_{\mathrm{it}}+\alpha_{15} \mathrm{R}_{\mathrm{it}} \mathrm{MB}_{\mathrm{it}}+\alpha_{16} \mathrm{BN}_{\mathrm{it}} \mathrm{R}_{\mathrm{it}} \mathrm{MB}_{\mathrm{it}}+$

$+\alpha_{17} \mathrm{LEV}_{\mathrm{it}}+\alpha_{18} \mathrm{BN}_{\mathrm{it}} \mathrm{LEV}_{\mathrm{it}}+\alpha_{19} \mathrm{R}_{\mathrm{it}} \mathrm{LEV}_{\mathrm{it}}+\alpha_{20} \mathrm{BN}_{\mathrm{it}} \mathrm{R}_{\mathrm{it}} \mathrm{LEV}_{\mathrm{it}}+$

$+\alpha_{21} \mathrm{BETA}_{\mathrm{it}}+\alpha_{22} \mathrm{BN}_{\mathrm{it}} \mathrm{BETA}_{\mathrm{it}}+\alpha_{23} \mathrm{R}_{\mathrm{it}} \mathrm{BETA}_{\mathrm{it}}+\alpha_{24} \mathrm{BN}_{\mathrm{it}} \mathrm{R}_{\mathrm{it}} \mathrm{BETA}_{\mathrm{it}}+$

$+\alpha_{25} \mathrm{UCC}_{\mathrm{it}}+\alpha_{26} \mathrm{BN}_{\mathrm{itt}} \mathrm{UCC}_{\mathrm{it}}+\alpha_{27} \mathrm{R}_{\mathrm{it}} \mathrm{UCC}_{\mathrm{it}}+\alpha_{28} \mathrm{BN}_{\mathrm{it}} \mathrm{R}_{\mathrm{it}} \mathrm{UCC}_{\mathrm{it}}+\zeta_{\text {it }}$

$\mathrm{R}_{\mathrm{it}} \quad$ market return of firm $\mathrm{i}$ in year $\mathrm{t}$, net of dividends and capital contributions;

$\mathrm{NI}_{\mathrm{it}} \quad$ net income of firm $\mathrm{i}$ in year $\mathrm{t}$, scaled by beginning of the period market value;

$\mathrm{BN}_{\mathrm{it}} \quad$ is a dummy variable equal to 1 if $\mathrm{R}_{\mathrm{it}}$ is negative and 0 otherwise;

IFRS $_{\mathrm{it}} \quad$ is a dummy variable equal to 1 if the year is 2005, 2006 or 2007 and 0 otherwise;

SIZE $_{\text {it }} \quad \log$ of the market value of firm $i$ at the end of the year $t$;

$\mathrm{MB}_{\text {it }} \quad$ market-to-book ratio of firm $\mathrm{i}$ at the end of the year $\mathrm{t}$;

$\mathrm{LEV}_{\text {it }} \quad$ leverage of firm $i$ at the end of the year $t$, defined as total debt scaled by market value;

BETA $_{\text {it }} \quad$ beta coefficient of firm $\mathrm{i}$ in year $\mathrm{t}$;

$\mathrm{UCC}_{\mathrm{it}} \quad$ measure of unconditional conservatism of firm $\mathrm{i}$ in year $\mathrm{t}$.

All continuous variables are winsorized at 5\%. Standard errors adjusted for clustering at firm level. t-statistics into brackets. *, **,*** indicates statistically significant at $0.10,0.05$ and 0.01 respectively. 
Table 3. The relative importance of enforcement and corporate governance

\begin{tabular}{|c|c|c|c|c|c|c|c|c|c|c|c|c|}
\hline \multirow[b]{2}{*}{ Before } & \multicolumn{2}{|c|}{$\mathrm{ENF}=0$} & \multicolumn{2}{|c|}{$\mathrm{ENF}=1$} & \multicolumn{2}{|l|}{$\Delta$} & \multicolumn{2}{|c|}{ GOV7=0 } & \multicolumn{2}{|c|}{ GOV7=1 } & \multicolumn{2}{|l|}{$\Delta$} \\
\hline & $\begin{array}{c}0.150 \\
(2.23)\end{array}$ & ** & $\begin{array}{c}0.314 \\
(5.20)\end{array}$ & $* * *$ & $\begin{array}{c}0.164 \\
(3.25)\end{array}$ & $* * *$ & $\begin{array}{c}0.185 \\
(2.76)\end{array}$ & $* * *$ & $\begin{array}{c}0.289 \\
(4.83)\end{array}$ & $* * *$ & $\begin{array}{c}0.104 \\
(2.11)\end{array}$ & $* *$ \\
\hline After & $\begin{array}{c}0.118 \\
(1.78)\end{array}$ & * & $\begin{array}{c}0.224 \\
(3.20)\end{array}$ & $* * *$ & $\begin{array}{l}0.106 \\
(2.46)\end{array}$ & $* *$ & $\begin{array}{r}0.126 \\
(1.89)\end{array}$ & $*$ & $\begin{array}{l}0.200 \\
(2.91)\end{array}$ & $* * *$ & $\begin{array}{l}0.075 \\
(1.73)\end{array}$ & $*$ \\
\hline$\Delta$ & $\begin{array}{r}-0.032 \\
(-0.63) \\
\end{array}$ & & $\begin{array}{r}-0.090 \\
(-2.29) \\
\end{array}$ & $* *$ & $\begin{array}{r}-0.058 \\
(-0.91)\end{array}$ & & $\begin{array}{r}-0.060 \\
(-1.22)\end{array}$ & & $\begin{array}{r}-0.088 \\
(-2.18)\end{array}$ & $* *$ & $\begin{array}{r}-0.029 \\
(-0.46)\end{array}$ & \\
\hline
\end{tabular}

Sample consists of European mandatory adopters of IFRS in 2005 from 16 countries (Austria, Belgium, Denmark, Finland, France, Germany, Great Britain, Greece, Ireland, Italy, Netherlands, Norway, Portugal, Spain, Sweden, and Switzerland). Sample period spans 2002-2007.

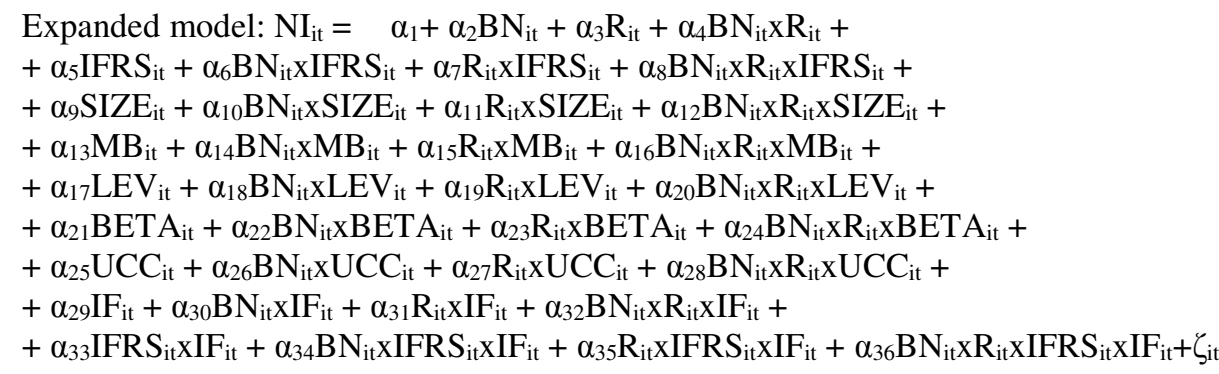

$\mathrm{R}_{\mathrm{it}} \quad$ market return of firm $\mathrm{i}$ in year $\mathrm{t}$, net of dividends and capital contributions;

$\mathrm{NI}_{\mathrm{it}} \quad$ net income of firm $\mathrm{i}$ in year $\mathrm{t}$, scaled by beginning of the period market value;

$\mathrm{BN}_{\mathrm{it}} \quad$ is a dummy variable equal to 1 if $\mathrm{R}_{\mathrm{it}}$ is negative and 0 otherwise;

IFRS $_{\text {it }} \quad$ is a dummy variable equal to 1 if the year is 2005, 2006 or 2007 and 0 otherwise;

SIZE $_{\text {it }} \quad \log$ of the market value of firm $i$ at the end of the year $t$;

$\mathrm{MB}_{\mathrm{it}} \quad$ market-to-book ratio of firm $\mathrm{i}$ at the end of the year $\mathrm{t}$;

$\mathrm{LEV}_{\mathrm{it}} \quad$ leverage of firm $\mathrm{i}$ at the end of the year $\mathrm{t}$, defined as total debt scaled by market value;

BETA $_{\text {it }}$ beta coefficient of firm $\mathrm{i}$ in year $\mathrm{t}$;

$\mathrm{UCC}_{\mathrm{it}} \quad$ measure of unconditional conservatism of firm $\mathrm{i}$ in year $\mathrm{t}$.

$\mathrm{IF}_{\text {it }} \quad$ is a dummy variable equal to 1 if a firm belongs to the specific group and 0 otherwise.

ENF is from Leuz et al. (2003) and represents the average of three proxies measuring law enforcement from La Porta et al. (1998). GOV7 is from Aggarwal et al. (2009) and represent an index of corporate governance quality at national level and is based on seven individual governance characteristics that have received the most attention in the academic literature.

All other variables defined in table 2. All continuous variables are winsorized at 5\%. Standard errors adjusted for clustering at firm level. t-statistics into brackets. $*, * *, * * *$ indicates statistically significant at $0.10,0.05$ and 0.01 respectively.

Reported measures of conditional conservatism:

\begin{tabular}{llll} 
& \multicolumn{1}{c}{$\mathrm{IF}_{\mathrm{it}}=0$} & \multicolumn{1}{c}{$\mathrm{IF}_{\mathrm{it}}=1$} & \multicolumn{1}{c}{$\Delta$} \\
Before IFRS $_{\mathrm{it}}=0$ & $\alpha_{4}+\alpha_{12}+\alpha_{16}+\alpha_{20}+\alpha_{24}+\alpha_{28}$ & $\alpha_{4}+\alpha_{12}+\alpha_{16}+\alpha_{20}+\alpha_{24}+\alpha_{28}+\alpha_{32}$ & $\alpha_{32}$ \\
After IFRS $_{\mathrm{it}}=1$ & $\alpha_{4}+\alpha_{8}+\alpha_{12}+\alpha_{16}+\alpha_{20}+\alpha_{24}+\alpha_{28}$ & $\alpha_{4}+\alpha_{8}+\alpha_{12}+\alpha_{16}+\alpha_{20}+\alpha_{24}+\alpha_{28}+\alpha_{32}+\alpha_{36}$ & $\alpha_{32}+\alpha_{36}$ \\
\cline { 2 - 5 }$\Delta$ & $\alpha_{8}$ & $\alpha_{8}+\alpha_{36}$ & $\alpha_{36}$
\end{tabular} 
Table 4. Combining Enforcement, Governance, Market type and Legal regime

\begin{tabular}{|c|c|c|c|c|c|c|}
\hline & \multicolumn{2}{|l|}{ Rest } & \multicolumn{2}{|c|}{ Cluster 1} & \multicolumn{2}{|l|}{$\Delta$} \\
\hline Before & $\begin{array}{l}0.256 \\
(4.30)\end{array}$ & $* * * *$ & $\begin{array}{r}0.282 \\
(3.95)\end{array}$ & $* * *$ & $\begin{array}{l}0.026 \\
(0.50)\end{array}$ & \\
\hline After & $\begin{array}{l}0.183 \\
(2.82) \\
\end{array}$ & $* * *$ & $\begin{array}{r}0.146 \\
(1.86)\end{array}$ & $*$ & $\begin{array}{l}-0.037 \\
(-0.74)\end{array}$ & \\
\hline \multirow[t]{2}{*}{$\Delta$} & $\begin{array}{r}-0.073 \\
(-2.04) \\
\end{array}$ & $* *$ & $\begin{array}{r}-0.136 \\
(-2.21) \\
\end{array}$ & $* *$ & $\begin{array}{l}-0.064 \\
(-0.91) \\
\end{array}$ & \\
\hline & \multicolumn{2}{|l|}{ Rest } & \multicolumn{2}{|c|}{ Cluster 2} & $\Delta$ & \\
\hline Before & $\begin{array}{l}0.213 \\
(3.24)\end{array}$ & $* * *$ & $\begin{array}{l}0.291 \\
(4.90)\end{array}$ & $* * *$ & $\begin{array}{l}0.078 \\
(1.63)\end{array}$ & \\
\hline After & $\begin{array}{r}0.134 \\
(2.02) \\
\end{array}$ & $* *$ & $\begin{array}{l}0.194 \\
(2.87) \\
\end{array}$ & $* * *$ & $\begin{array}{l}0.060 \\
(1.43)\end{array}$ & \\
\hline \multirow[t]{2}{*}{$\Delta$} & $\begin{array}{r}-0.078 \\
(-1.63)\end{array}$ & & $\begin{array}{l}-0.097 \\
(-2.37)\end{array}$ & $* *$ & $\begin{array}{l}-0.019 \\
(-0.30)\end{array}$ & \\
\hline & \multicolumn{2}{|l|}{ Rest } & \multicolumn{2}{|c|}{ Cluster 3} & $\Delta$ & \\
\hline Before & $\begin{array}{l}0.287 \\
(4.90)\end{array}$ & $* * *$ & $\begin{array}{l}0.030 \\
(0.36)\end{array}$ & & $\begin{array}{l}-0.257 \\
(-3.84)\end{array}$ & $* * *$ \\
\hline After & $\begin{array}{l}0.181 \\
(2.69)\end{array}$ & $* * *$ & $\begin{array}{l}0.139 \\
(2.02)\end{array}$ & $* *$ & $\begin{array}{l}-0.042 \\
(-0.91)\end{array}$ & \\
\hline$\Delta$ & $\begin{array}{l}-0.106 \\
(-3.02) \\
\end{array}$ & $* * * *$ & $\begin{array}{r}0.110 \\
(1.44) \\
\end{array}$ & & $\begin{array}{r}0.216 \\
(2.57) \\
\end{array}$ & $* *$ \\
\hline
\end{tabular}

Sample consists of European mandatory adopters of IFRS in 2005 from 16 countries (Austria, Belgium, Denmark, Finland, France, Germany, Great Britain, Greece, Ireland, Italy, Netherlands, Norway, Portugal, Spain, Sweden, and Switzerland). Sample period spans 2002-2007.

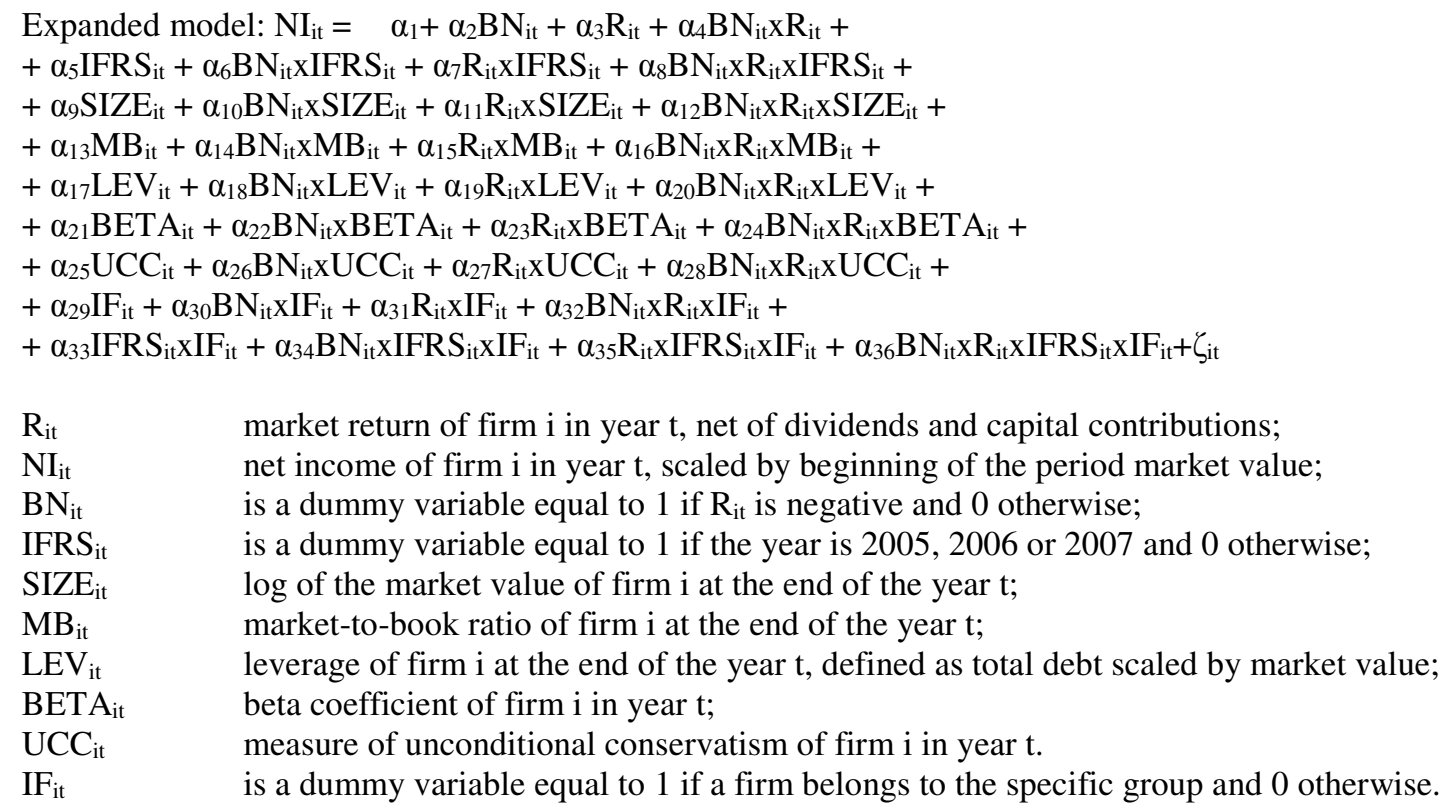


The clusters are based on Leuz et al. (2003) which groups countries based on similar legal and institutional characteristics into three groups: Cluster 1 includes countries with outsider economies and large stock markets, dispersed ownership and strong investors rights and legal enforcement (Great Britain and Norway); Cluster 2 have insider economies and less developed stock markets, concentrated ownership, weak investor rights but strong enforcement (Austria, Belgium, Denmark, Finland, France, Germany, Ireland, Netherlands, Sweden, and Switzerland); Cluster 3 consists of insider economies with weak enforcement (Greece, Italy, Portugal, and Spain).

Reported measures of conditional conservatism:

\begin{tabular}{lll|l} 
& \multicolumn{1}{c}{$\mathrm{IF}_{\text {it }}=0$} & \multicolumn{1}{c}{$\mathrm{IF}_{\text {it }}=1$} & \multicolumn{1}{c}{$\Delta$} \\
Before IFRS $_{\text {it }}=0$ & $\alpha_{4}+\alpha_{12}+\alpha_{16}+\alpha_{20}+\alpha_{24}+\alpha_{28}$ & $\alpha_{4}+\alpha_{12}+\alpha_{16}+\alpha_{20}+\alpha_{24}+\alpha_{28}+\alpha_{32}$ & $\alpha_{32}$ \\
After IFRS $_{\text {it }}=1$ & $\alpha_{4}+\alpha_{8}+\alpha_{12}+\alpha_{16}+\alpha_{20}+\alpha_{24}+\alpha_{28}$ & $\alpha_{4}+\alpha_{8}+\alpha_{12}+\alpha_{16}+\alpha_{20}+\alpha_{24}+\alpha_{28}+\alpha_{32}+\alpha_{36}$ & $\alpha_{32}+\alpha_{36}$ \\
\cline { 2 - 5 }$\Delta$ & $\alpha_{8}$ & $\alpha_{8}+\alpha_{36}$ & $\alpha_{36}$
\end{tabular}

All continuous variables are winsorized at 5\%. Standard errors adjusted for clustering at firm level. $t$-statistics into brackets. $* * * * * *$ indicates statistically significant at $0.10,0.05$ and 0.01 respectively. 
Table 5. The relative importance of intangibles and goodwill

\begin{tabular}{|c|c|c|c|c|c|c|c|c|c|c|c|c|}
\hline \multirow[b]{2}{*}{ Before } & \multicolumn{2}{|c|}{ DINT $=0$} & \multicolumn{2}{|c|}{ DINT $=1$} & \multicolumn{2}{|l|}{$\Delta$} & \multicolumn{2}{|c|}{$\mathrm{DGW}=0$} & \multicolumn{2}{|c|}{$\mathrm{DGW}=1$} & \multicolumn{2}{|l|}{$\Delta$} \\
\hline & $\begin{array}{l}0.288 \\
(3.28)\end{array}$ & $* * *$ & $\begin{array}{l}0.252 \\
(4.26)\end{array}$ & $* * *$ & $\begin{array}{l}-0.036 \\
(-0.46)\end{array}$ & & $\begin{array}{l}0.248 \\
(3.78)\end{array}$ & $* * *$ & $\begin{array}{l}0.261 \\
(4.23)\end{array}$ & *** & $\begin{array}{l}0.012 \\
(0.24)\end{array}$ & \\
\hline After & $\begin{array}{r}0.462 \\
(3.81) \\
\end{array}$ & $* * *$ & $\begin{array}{l}0.148 \\
(2.28) \\
\end{array}$ & $* *$ & $\begin{array}{l}-0.314 \\
(-2.82)\end{array}$ & $* * *$ & $\begin{array}{l}0.190 \\
(2.70) \\
\end{array}$ & $* * *$ & $\begin{array}{r}0.155 \\
(2.26) \\
\end{array}$ & $* *$ & $\begin{array}{l}-0.035 \\
(-0.67)\end{array}$ & \\
\hline \multirow[t]{2}{*}{$\Delta$} & $\begin{array}{r}0.174 \\
(1.37) \\
\end{array}$ & & $\begin{array}{l}-0.104 \\
(-3.22)\end{array}$ & $* * *$ & $\begin{array}{l}-0.278 \\
(-2.12) \\
\end{array}$ & $* *$ & $\begin{array}{c}-0.058 \\
(-0.97) \\
\end{array}$ & & $\begin{array}{l}-0.106 \\
(-2.81) \\
\end{array}$ & *** & $\begin{array}{r}-0.047 \\
(-0.66) \\
\end{array}$ & \\
\hline & DIMPII & $T=0$ & DIMPIN & $T=1$ & $\Delta$ & & DIMPG & $\mathrm{W}=\mathbf{0}$ & DIMPG & $N=1$ & $\Delta$ & \\
\hline Before & $\begin{array}{l}0.239 \\
(4.20)\end{array}$ & $* * *$ & $\begin{array}{l}0.459 \\
(4.96)\end{array}$ & $* * *$ & $\begin{array}{l}0.220 \\
(2.73)\end{array}$ & $* * *$ & $\begin{array}{l}0.238 \\
(4.17)\end{array}$ & $* * *$ & $\begin{array}{l}0.456 \\
(4.52)\end{array}$ & $* * *$ & $\begin{array}{l}0.219 \\
(2.44)\end{array}$ & $* *$ \\
\hline After & $\begin{array}{l}0.180 \\
(2.87) \\
\end{array}$ & $* * *$ & $\begin{array}{l}0.219 \\
(2.68) \\
\end{array}$ & $* * *$ & $\begin{array}{l}0.039 \\
(0.68)\end{array}$ & & $\begin{array}{l}0.188 \\
(2.99) \\
\end{array}$ & $* * *$ & $\begin{array}{l}0.166 \\
(1.84) \\
\end{array}$ & $*$ & $\begin{array}{l}-0.022 \\
(-0.33)\end{array}$ & \\
\hline$\Delta$ & $\begin{array}{r}-0.059 \\
(-1.82) \\
\end{array}$ & $*$ & $\begin{array}{r}-0.240 \\
(-2.56) \\
\end{array}$ & $* *$ & $\begin{array}{r}-0.181 \\
(-1.84) \\
\end{array}$ & $*$ & $\begin{array}{r}-0.050 \\
(-1.56) \\
\end{array}$ & & $\begin{array}{l}-0.291 \\
(-2.74) \\
\end{array}$ & $* * *$ & $\begin{array}{r}-0.240 \\
(-2.19) \\
\end{array}$ & ** \\
\hline
\end{tabular}

Sample consists of European mandatory adopters of IFRS in 2005 from 16 countries (Austria, Belgium, Denmark, Finland, France, Germany, Great Britain, Greece, Ireland, Italy, Netherlands, Norway, Portugal, Spain, Sweden, and Switzerland). Sample period spans 2002-2007.

DINTit is a dummy variable equal to 1 if INTAN It $_{\text {it }}$ is positive, and 0 otherwise;

$\mathrm{DGW}_{\text {it }} \quad$ is a dummy variable equal to 1 if the goodwill of firm $\mathrm{i}$ at the end of the year $\mathrm{t}$ is positive, and 0 otherwise;

DIMPINTit is a dummy variable equal to 1 if DINTAN $_{\text {it }}$ is 1 and the intangibles have been impaired during the year $\mathrm{t}$, and 0 otherwise;

DIMPGW $_{\text {it }}$ is a dummy variable equal to 1 if the goodwill of firm $i$ at the end of the year $t$ is positive and the goodwill has been impaired during the year $t$, and 0 otherwise.

Reported measures of conservatism: see table 3

All continuous variables are winsorized at 5\%. Standard errors adjusted for clustering at firm level. t-statistics into brackets. ***,*** indicates statistically significant at $0.10,0.05$ and 0.01 respectively. 
ESSEC Business School Avenue Bernard Hirsch BP 50105

95021 Cergy-Pontoise Cedex France

Tél. +33(0)134433000

$\mathrm{Fax}+33(0) 134433001$

www.essec.fr

\section{ESSEC Executive Education} CNIT BP 230

92053 Paris-La Défense France

Tél. +33(0)146924900

Fax +33 (0)1 46924990

http://formation.essec.fr

ESSEC Business School

Singapore Campus

100 Victoria Street

National Library Building \# 13-02

Singapore 188064

essecasia@essec.fr

Tél. +6568849780

Fax +6568849781

www.essec.edu

Informations

Alison Bougi

+33 (0)134433358

bougi@essec.fr

www.essec.fr

research.center@essec.fr

ISSN 1291-9616 